\title{
La aplicación de análisis térmico a las reacciones de hidratación y conversión de cementos aluminosos
}

\section{The application of thermal analysis to the hydration and conversion Reactions of calcium aluminate Cements}

\author{
S. M. BUSHNELL-WATSON y J. H. SHARP
}

Departamento de Materiales de Ingenieria, Universidad de Sheffield. Sheffield REINO UNIDO

Fecha de recepción: 16-VII-92

\section{RESUMEN}

La hidratación de cementos aluminosos está regida por la de $\mathrm{CA}, \mathrm{CaAl}_{2} \mathrm{O}_{4}$, que es el componente principal. $\mathrm{A}$ temperatura ambiente inicialmente se forman $\mathrm{CAH}_{10}$ y una fase amorfa, pero son metaestables y se transforman lentamente (o más rápidamente si se exponen a temperaturas más altas) en $C_{3} A H_{6}$ y gibsita. Esta reacción de conversión está acompañada de un aumento de porosidad, lo que lleva a la pérdida de resistencia y a la vulnerabilidad al ataque químico. Se han aplicado distintos métodos de análisis térmico como una prueba rutinaria para determinar el grado de conversión y se ofrece una evaluación crítica de los resultados de estos métodos. Análisis térmico es una técnica útil para identificar los distintos hidratos que pueden formarse en estos sistemas, especialmente en las etapas iniciales de la hidratación cuando están presentes las fases pobremente cristalinas. Se presentan curvas diferenciales de análisis térmico que muestran picos atribuibles a todos estos hidratos y se demuestra que, frecuentemente, ocurre superposición que produce dificultades en interpretación, las que a veces pueden hacerse menores utilizando técnicas como la difracción de rayos $X$.

\section{$S \cup M M A R Y$}

The hydration of calcium aluminate cements is dominated by that of $\mathrm{CA}, \mathrm{CaAl}_{2} \mathrm{O}_{4}$, which is a major constituent of all of them. At ambient temperatures, $C A H_{10}$ and an amorphous phase are formed initially, but these are metastable and slowly (or more rapidly if exposed to higher temperatures) transform into $C_{3} A H_{6}$ and gibbsite. This conversion reaction is accompanied by and increase in porosity, which can lead to a loss in strength and vulnerability to chemical attack. Various methods of thermal analysis have been applied as a routine test to determine the degree of conversion, and the results from these methods are critically evaluated. Thermal analysis is a useful technique for identification of the various hydrates that can form in these systems, especially at early stages of hydration when poorly crystalline phases are present. Differential thermal analysis curves showing peaks attributable to all these hydrates are presented and it is shown that overlap frequently occurs, leading to difficulties in interpretation, which can sometimes be minimised by use of a complementary technique such as $X$-ray diffraction.

\section{INTRODUCCIÓN}

\section{a) Cementos aluminosos}

Los cementos aluminosos son un grupo de materiales cementícios interrelacionados con contenidos de aluminato, variando entre unos $38 \%$ hasta $90 \%$, que incorporan monoaluminato de calcio $\left(\mathrm{CaAl}_{2} \mathrm{O}_{4}\right.$ ó CA) como componente principal. Fases secundarias están siempre presentes, pero varían en la proporción cal/alumina y nivel de impurezas, especialmente sílice y hierro (1-7). El cemento más conocido de éstos es ciment fondu, al que se refiere

\section{INTRODUCTION}

\section{a) Calcium aluminate cements}

Calcium aluminate cements are a group of interrelated cementitious materials, with alumina contents varying from about $38 \%$ to $90 \%$, which incorporate calcium monoaluminate $\left(\mathrm{CaAl}_{2} \mathrm{O}_{4}\right.$ or $C A)$ as the major constituent. Second phases are always present, but vary with the lime:alumina ratio and with the level of impurities, especially silicon and iron (1-7). The best known of these cements is ciment fondu which is commonly referred to as high alumina cement as it has a 
generalmente como a cemento de alto contenido en alúmina, mucho más alto que el de cemento portland. No obstante, este término es ambiguo (3), ya que su contenido de alúmina es más bajo que el de los cementos más refractarios con el contenido de $\mathrm{Al}_{2} \mathrm{O}_{3}$ de $70 \%$ o más. Por lo tanto, el término cementos aluminosos es una descripción más exacta de esta clase de cementos.

El ciment fondu tiene aproximadamente iguales cantidades de $\mathrm{CaO}$ y $\mathrm{Al}_{2} \mathrm{O}_{3}(38-40 \%)$, y además de $C A$ siempre contiene una cantidad significativa de $C_{12} A_{7}$. También contiene $C_{2} A S$ ( $y$ a veces $\mathrm{C}_{2} \mathrm{~S}$ ), una fase ferrítica que le da un color gris oscuro y pleocroíta (8).

Los cementos más refractarios, $>70 \% \mathrm{Al}_{2} \mathrm{O}_{3}$, normalmente tienen poco hierro y sílice $y$, por lo tanto, son de color blanco y pertenecen prácticamente al sistema binario $\mathrm{CaO}-\mathrm{Al}_{2} \mathrm{O}_{3}$. En cierta época hubo incertidumbre acerca de la composición de las fases anhidras en este sistema, pero ahora están establecidas como $C_{3} A, C_{12} A_{7}$ (que pueden contener grupos $O H$ ), $\mathrm{CA}, \mathrm{CA}_{2}$ y $\mathrm{CA}_{6}$. Aunque el $\mathrm{C}_{3} \mathrm{~A}$ tiene gran importancia para los cementos portland, en el cemento aluminoso no existe, ya que consiste en una mezcla de $C A$ y $\mathrm{CA}_{2}$, con pequeña (pero importante) proporción de $\mathrm{C}_{12} \mathrm{~A}_{7}$ y $\alpha-\mathrm{Al}_{2} \mathrm{O}_{3}$ no reaccionado. Cementos con el contenido de $\mathrm{Al}_{2} \mathrm{O}_{3}$ de $80 \%$ o más no son correctos y, aunque pueden contener una mayor proporción de $\mathrm{CA}_{2} \mathrm{jCA}$, frecuentemente tienen un contenido de $\alpha-\mathrm{Al}_{2} \mathrm{O}_{3}$ considerablemente más alto.

En las tablas 1 y 2 se muestran ejemplos generales de las composiciones química y mineralógica de varios cementos aluminosos. much higher alumina cement as it content than Portland cement. However, this is an ambigouos term (3) since its alumina content is much lower than the more refractory cements with $\mathrm{Al}_{2} \mathrm{O}_{3}$ contents of $70 \%$ and above. The term calcium aluminate cements is therefore a more accurate description of this class of cements.

Ciment fondu has approximately equal amounts of $\mathrm{CaO}$ and $\mathrm{Al}_{2} \mathrm{O}_{3}(38-40 \%)$ and in addition to $\mathrm{CA}$ always contains a significant amount of $C_{12} a_{7}$. $C_{2} A S$ (and sometimes $C_{2} S$ ) a ferrite phase, which gives it a dark grey colour, and pleochorite (8) will also be present.

The most refractory cements, i.e. $>70 \% \mathrm{Al}_{2} \mathrm{O}_{3}$, are usually low in iron and silicon and are, therefore, white in colour and almost pure members of the $\mathrm{CaO}-\mathrm{Al}_{2} \mathrm{O}_{3}$ binary system. There was at one time uncertainty about the composition of the anhydrous phases in this system, but they are now established as $C_{3} A, C_{12} A_{7}$ (which may contain $\mathrm{OH}$ groups), $\mathrm{CA}, \mathrm{CA}_{2}$ and $\mathrm{CA}_{6}$. Although $C_{3} A$ is of major importance in Portland cements, it is absent in calcium aluminate cement consists of a mixture of $C A$ and $C A_{2}$, with perhaps a small (but important) amount of $C_{12} A_{7}$ and unreacted $\alpha-\mathrm{Al}_{2} \mathrm{O}_{3}$. Cements with $80 \%$ and above $\mathrm{Al}_{2} \mathrm{O}_{3}$ content are not equilibrium assemblages and although they may contain a higher proportion of $C A_{2}$ to $C A$, they often haven a considerably higher $\alpha-A l_{2} O_{3}$ content.

Shown in Tables 1 and 2 are general examples of the chemical and mineralogical compositions of various calcium aluminate cements.

TABLA 1 TABLE 1

Ejemplos de composiciones químicas de cementos aluminosos

Examples of chemical compositions of calcium aluminate cements

\begin{tabular}{|l|c|c|c|c|c|c|c|}
\hline & $\begin{array}{c}\text { Ciment } \\
\text { fondu }\end{array}$ & $\begin{array}{c}\text { Secar } \\
\mathbf{5 1}\end{array}$ & $\begin{array}{c}\text { Secar } \\
\mathbf{7 1}\end{array}$ & $\begin{array}{c}\text { Alcoa } \\
\text { CA-14 }\end{array}$ & $\begin{array}{c}\text { Alcoa } \\
\text { CA-25 }\end{array}$ & $\begin{array}{c}\text { Secar } \\
\mathbf{8 0}\end{array}$ & $\begin{array}{c}\text { Denka } \\
\text { S-90 }\end{array}$ \\
\hline $\mathrm{Al}_{2} \mathrm{O}_{3}$ & 38,7 & 50,4 & 71,0 & 72,0 & 80,4 & 80,5 & 88,1 \\
$\mathrm{CaO}$ & 38,5 & 36,6 & 27,0 & 28,0 & 17,6 & 18,0 & 9,7 \\
$\mathrm{MgO}$ & 0,02 & 0,1 & 0,2 & 0,25 & 0,10 & 0,1 & 0 \\
$\mathrm{SiO}_{2}$ & 4,14 & 6,7 & 0,35 & 0,45 & 0,2 & 0,2 & 0,08 \\
$\mathrm{Fe}_{2} \mathrm{O}_{3}$ & 10,43 & 1,9 & 0,25 & 0,1 & 0,26 & 0,15 & 0,18 \\
$\mathrm{Na}_{2} \mathrm{O}$ & 0,06 & 0,1 & 0,35 & 0,38 & 0,6 & 0,25 & 1,00 \\
$\mathrm{FeO}$ & 5,63 & 1,0 & - & - & - & - & - \\
$\mathrm{TiO}_{2}$ & 1,98 & 2,15 & 0,05 & 0 & 0,02 & 0,03 & 0,03 \\
\hline
\end{tabular}


TABLA 2 TABLE 2

Ejemplos de composición mineralógica de cementos aluminosos Examples of mineralogical compositions of calcium aluminate cements

\begin{tabular}{|c|c|c|c|c|c|c|c|}
\hline & $\begin{array}{l}\text { Ciment } \\
\text { fondu }\end{array}$ & $\begin{array}{c}\text { Secar } \\
51\end{array}$ & $\begin{array}{c}\text { Secar } \\
71\end{array}$ & $\begin{array}{l}\text { Alcoa } \\
\text { CA-14 }\end{array}$ & $\begin{array}{l}\text { Alcoa } \\
\text { CA-25 }\end{array}$ & $\begin{array}{c}\text { Secar } \\
80\end{array}$ & $\begin{array}{c}\text { Denka } \\
\text { S-90 }\end{array}$ \\
\hline $\mathrm{CA}$ & $\star \star * *$ & $\star \star \star *$ & $* * *$ & $\star \star \star \star$ & $\star \star \star *$ & $\star \star \star *$ & $\star \star \star *$ \\
\hline $\mathrm{CA}_{2}$ & - & - & $\star \star \star \star$ & $\star \star \star *$ & $*$ & 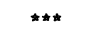 & $\star$ \\
\hline$C_{12} A_{7}$ & * & * & $\star$ & * & * & * & * \\
\hline A & - & * & * & * & $\star \star \star \star$ & $\star \star \star \star$ & $\star \star \star \star$ \\
\hline $\mathrm{C}_{2} \mathrm{~S}$ & * & - & - & - & - & - & - \\
\hline $\mathrm{C}_{2} \mathrm{AS}$ & * & * & - & - & - & - & - \\
\hline $\mathrm{C}_{4} \mathrm{AF}$ & " & * & - & - & - & - & - \\
\hline
\end{tabular}

${ }^{* *}$ = componente principal (major component), ${ }^{*}=$ fase secundaria (secondary phase).

\section{b) Reacciones de conversión}

En todos los cementos aluminosos, el CA es el componente principal. EI CA reacciona con agua para formar una serie de hidratos de aluminato de calcio que varían en temperatura y tiempo $(2-4,9)$, como se resume en figura 1 [según Parker y Sharp (3)]. A temperaturas bajas $\left(<18^{\circ} \mathrm{C}\right)$ el único hidrato cristalino que se forma es $\mathrm{CAH}_{10}$, aunque también se forma una fase amorfa en cantidades considerables (10). Por regla general, se considera que esta fase amorfa es alúmina gel, pero Payne y Sharp (11) han sostenido que eso debe de ser una fase C-A-H (fase que contiene un hidrato de aluminato de calcio hidratado de composición desconocida), ya que no se forman ni $\mathrm{CH}$ ni hidratos de aluminato ricos en calcio para mantener el equilibrio químico. A temperaturas más altas, y en

\section{b) Conversión Reactions}

In all the calcium aluminate cements $C A$ is the major component. $C A$ reacts with water to form a series of calcium aluminate hydrates which vary with temperature and time $(2-4,9)$ as summarised in Figure 1 [after Parker and Sharp (3)]. At low temperatures $\left(<18^{\circ} \mathrm{C}\right)$ the only crystalline hydrate formed is $C A H_{10}$, although an amorphous phase is also formed in considerable amounts (10). This amorphous phase is usually taken to be alumina gel, but Payne and Sharp (11) have argued that it must be a $\mathrm{C}-\mathrm{A}-\mathrm{H}$ phase (i.e. one containing a calcium aluminate hydrate of unknown composition) since no $\mathrm{CH}$ or calcium rich aluminate hydrates are also formed to maintain a chemical balance. At higher temperatures, and in cements containing $C_{12} A_{7}, C_{2} A H_{8}$ is formed as well as or instead of $C_{10}$ (12). Both of these

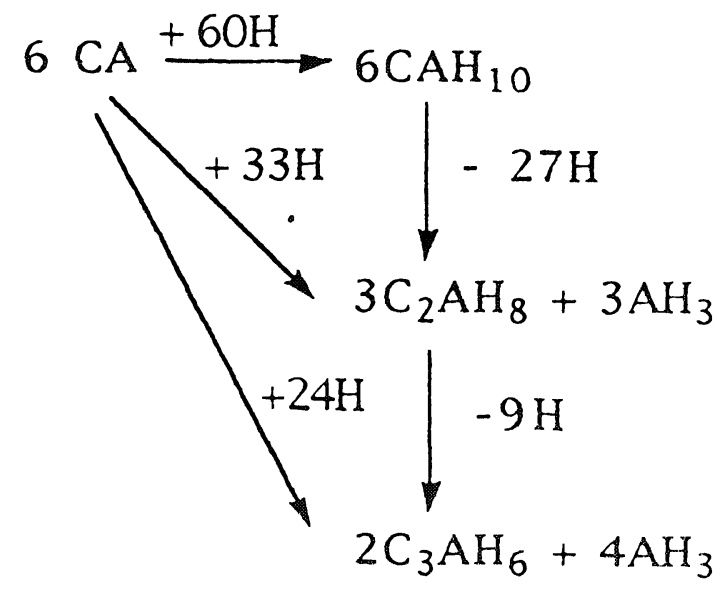

Fig. 1.-Esquema de reacción para la hidratación de CA.

Fig. 1.-Reaction scheme for the hydration of $C A$. 
cementos que contienen $C_{12} A_{7}$, se puede formar $\mathrm{C}_{2} \mathrm{AH}_{8}$ en vez de $\mathrm{CAH}_{10}$ (12), 0 además de éste. Ambos hidratos son hexagonales en morfología y termodinámicamente metaestables. Por encima de $28^{\circ} \mathrm{C}$ ellos "se convierten" con relativa rapidez en $\mathrm{C}_{3} \mathrm{AH}_{6}$, que tiene una estructura cúbica relacionada con la de grosularita, $\left(\mathrm{C}_{3} \mathrm{AS}_{3}\right)$, y gibsita, $\mathrm{AH}_{3}$ ó $\mathrm{Al}(\mathrm{OH})_{3}$. Las ecuaciones para estas reacciones de conversión se pueden escribir como:

$$
\begin{aligned}
3 \mathrm{CAH}_{10} & =\mathrm{C}_{3} \mathrm{AH}_{6}+2 \mathrm{AH}_{3}+18 \mathrm{H} \\
3 \mathrm{C}_{2} \mathrm{AH}_{8} & =2 \mathrm{C}_{3} \mathrm{AH}_{6}+\mathrm{AH}_{3}+9 \mathrm{H}
\end{aligned}
$$

Se pueden hacer dos observaciones: Primera, el agua se forma como producto de las reacciones de conversión. Segunda, los productos de conversión son más densos que los hidratos hexagonales. Puesto que estas reacciones ocurren después de que el cemento haya fraguado y haya endurecido, se estabilizan las dimensiones totales del hormigón y por eso tiene que compensarse el cambio en densidad por un aumento en porosidad. Esto a su vez lleva a una pérdida de resistencia y a la posibilidad de desarrollo de microgrietas. La porosidad aumentada, también conduce hacia un aumento en permeabilidad, de manera que el hormigón y los refuerzos de metal llegan a ser más susceptibles al ataque químico por sales disueltas, ácidos o álcalis en aguas subterráneas.

A esa pérdida de resistencia, asociada con la conversión, se ha culpado de tres accidentes que ocurrieron en Reino Unido, en 1973-1974, cuando fallaron vigas de hormigón hechas del ciment fondu $(13,14)$. Sin embargo, como ya hemos mencionado anteriormente, el efecto de ataque químico ha podido ser tan importante como la pérdida de resistencia debida a la conversión, por ejemplo en la Escuela Sir John Cass,

Stepney (14). También se debería observar qué fallo puede ocurrir con un hormigón hecho de cualquier tipo de cemento, si se trabaja mal o con cálculos inadecuados; ambos son responsables, si bien sólo en parte, de los colapsos. Por tanto, la conversión en cementos aluminosos puede causar fallos. Cuando se diseña una estructura, siempre se debería tener en cuenta la reducción de resistencia que produce dicha conversión (14), a la cual no se puede culpar automáticamente en cada fallo que se ha producido. Tampoco se debería asumir que un grado de conversión en un cemento aluminoso conduce inevitablemente a un mal producto.

Casi todo el hormigón colocado más de dos años, con un alto grado de conversión, no necesariamente está en una situación peligrosa. Como se demuestra en un informe del año 1980 [Bate (15)], de un total de 30.000 a 50.000 edificios que contienen hormigón de cemento aluminoso, se realizaron 1.022 análisis, los cuales hydrates are hexagonal in morphology and thermodynamically metastable. Above $28^{\circ} \mathrm{C}$ they "convert" relatively rapidly into $C_{3} A S_{6}$, which has a cubic structure related to that of grossularite, $\mathrm{C}_{3} \mathrm{AS}_{3}$, and gibbsite, $\mathrm{AH}_{3}$ or $\mathrm{Al}(\mathrm{OH})_{3}$. The equations for these conversion reactions can be written as

$$
\begin{aligned}
3 C A H_{10} & =C_{3} A H_{6}+2 A H_{3}+18 H \\
3 C_{2} A H_{8} & =2 C_{3} A H_{6}+A H_{3}+9 H
\end{aligned}
$$

Two observations may be made. First, water is formed as a product of the conversion reactions. Second, the conversion products are denser than the hexagonal hydrates. Since these reactions take place after the cement has set and hardened, the overal dimensions of the concrete are fixed and so the change in density has to be accommodated by an increase in porosity. This in turn leads to a loss in strength and the possibility of microcracks developing. Also the increased porosity leads to an increase in permeability so that the concrete and metal reinforcement become more susceptible to chemical attack by dissolved salts, acids or alkalis in ground waters.

The loss of strength associated with conversion has been blamed, to a greater or lesser extent, for three accidents which occurred in the U.K. in 1973-1974 when concrete beams made from ciment fondu failed $(13,14)$. However, as mentioned above, the effect of chemical attack may have been as important as the loss of strength due to conversion, for example at the Sir John Cass School, Stepney (14). It should also be noted that failure can occur with concrete made from any type of cement if there is poor workmanship or suspect engineering design; both of which have been suggested as having been responsible, at least in part, for the collapses. Therefore, although conversión in calcium aluminate cements may cause failure and the strength reduction should always be taken into account when designing a structure (14), it cannot be blamed automatically for every failure that has occurred. Also, it should not be assumed that a highly converted calcium aluminate cement leads inevitably to a poor product.

Almost all concrete that has been laid for two years or more is highly converted, but is not necessarily in a dangerous condition. As shown in a 1980 report [Bate (15)] although $30,000-50,000$ buildings were estimated to contain calcium aluminate cement concrete, of 1,022 appraisals undertaken, only 38 buildings were identified as 
demostraron que sólo 38 edificios tenían problemas graves. El hormigón ha podido alcanzar el estado donde pasó por un punto mínimo y está, en realidad, ganando en resistencia (Fig. 2). Esto puede ocurrir cuando la proporción agua:cemento es baja $(\leq 0,4)$, así que sólo una parte de CA se hidrata inicialmente para formar $\mathrm{CAH}_{10}$ (se requiere una proporción a:c de 1,14 para convertir CA completamente en $\left.\mathrm{CAH}_{10}\right)$. Cuando ocurre la conversión de $\mathrm{CAH}_{10}$, el agua se libera según la ecuación (1) y entonces está disponible para hidratar algo del CA no reaccionado. Esta hidratación ocurre en los poros que se han desarrollado durante la conversión, reduciendo el volumen de los poros y aumentando la resistencia a compresión. De ahí que factores tales como la relación a:c y la velocidad de conversión son más importantes que la extensión de la conversión. El desarrollo de BRECEM por el Building Research Establishment, en el Reino Unido (16-18), ha sido una aproximación alternativa a este problema. Se trata de incorporar en el cemento escoria molida granulada de horno alto, para formar gehlenita hidratada o strätlingita, $\mathrm{C}_{2} A \mathrm{ASH}_{8}$, a través de la reacción de $\mathrm{CAH}_{10}$ con el vidrio de la escoria rico en sílice. Se afirma que la formación de esta fase, antes que la formación de $\mathrm{C}_{3} \mathrm{AH}_{6}$, contrarresta la pérdida de resistencia que se nota en ambientes cálidos y húmedos. being in a distressed condition. Indeed the concrete may have reached the stage where it has passed through a minimum and is actually gaining in strength (Figure 2). This can occur when the water: cement ratio is low $(\leq 0.4)$ so that only part of the CA hydrates initially to form $C A H_{10}$ (it requires a w:c ratio of 1.14 to convert $C A$ completely into $\mathrm{CAH}_{10}$ ). When conversión of $\mathrm{CAH}_{10}$ occurs, water is liberated according to equation (1) and is then available to hydrate some of the unreacted CA. This hydration takes places in the pores that have developed during the conversion and acts as a self-healing process to reduce the pore volume and increase the compressive strength. Hence factors such as the original w:c ratio and the rate of conversion are more important than the extent of conversion. An alternative approach to this problem has been the development of BRECEM by the Building Research Establishment in the U.K. (16-18), which incorporates ground, granulated blast furnace slag in the cement to form gehlenite hydrate or strätlingite, $\mathrm{C}_{2} \mathrm{ASH}_{8}$, by reaction of $\mathrm{CAH}_{10}$ with the silica-rich glass in the slag. The formation of this phase in preference to the formation of $\mathrm{C}_{3} A \mathrm{H}_{6}$ is claimed to counteract the loss in strength observed in hot and humid conditions.

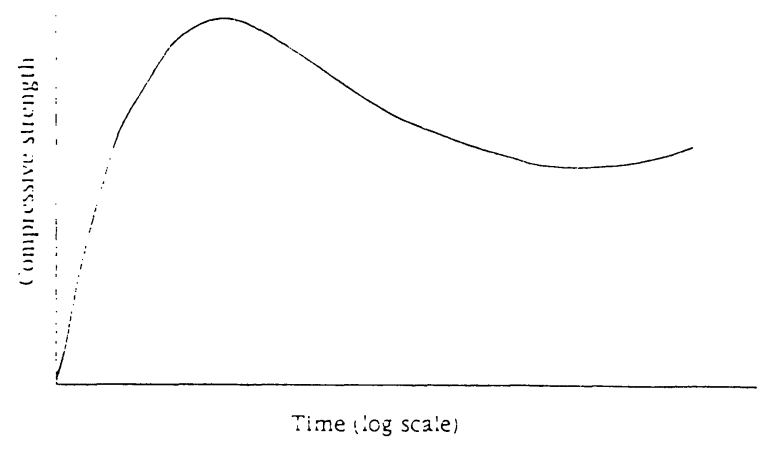

Fig. 2.-Variación en resistencia a compresión de pasta de cemento aluminoso con el transcurso del tiempo (esquemática).

Fig. 2.-Variation in compressive strength of calcium aluminate paste with time (schematic).

\section{c) Análisis térmico de cementos aluminosos} hidratados

Desafortunadamente es difícil establecer, de forma retrospectiva, si se había utilizado una proporción de a:c apropiada o no cuando el hormigón se colocó, o determinar la velocidad de conversión. En principio, es mucho más fácil medir la extensión, pero ni siquiera esto es sencillo en la práctica. Aunque la presencia de los hidratos principales $\mathrm{CAH}_{10}, \mathrm{C}_{3} \mathrm{AH}_{6}$ y $\mathrm{AH}_{3}$ se c) Thermal analysis of hydrated calcium aluminate cements

Unfortunately it is difficult to establish retrospectively whether or not a suitable w:c ratio was used when the concrete was placed or to determine the rate of conversion. It is much easier in principle to measure the estent of conversion, but even this is not straightforward in practice. Although the presence of the major hydrates, $C A H_{10}, C_{3} A H_{6}$ and $A H_{3}$, can be detected by $X$-ray 
puede detectar por la difracción de rayos $X$ (DRX), los picos no se pueden utilizar con facilidad para análisis cuantitativo. Puede ocurrir orientación preferente con fases hexagonales como $\mathrm{CAH}_{10}$ y también puede que los hidratos no estén totalmente cristalizados, especialmente en las etapas iniciales de la hidratación. Existen algunas fases que son amorfas por naturaleza, las fases de gel, y la presencia de éstas no se detectará por DRX. Por lo tanto el uso de técnicas de análisis térmico es muy importante en el estudio de cementos, ya que proporciona información sobre las fases hidratadas presentes en las etapas iniciales de hidratación, cuando esto no es posible con la DRX. No obstante, la comparación de la curva de análisis térmico con datos de una técnica complementaria (habitualmente DRX) permite una interpretación más clara.

Varios métodos del análisis, es decir análisis térmico diferencial (ATD), calorimetría diferencial (DSC) y termogravimetría (DTG) se han aplicado para determinar el grado de conversión, $\alpha, y$ así permitir conocer perfectamente la estructura que se debe evaluar. Estas técnicas están bien explicadas en clásicos libros de texto sobre análisis térmico, como los de Wendlandt (19), Daniels (20), y Dodd y Tonge (21), que incluyen ejemplos típicos referentes a la aplicación de métodos térmicos a la determinación del grado de conversión. En el informe (22), editado por el Thermal Methods Group del Royal Society for Chemistry, se discuten recomendaciones para los ensayos con métodos térmicos de hormigón hecho con cemento aluminoso.

Como parte de una investigación detallada del comportamiento en el fraguado, y la hidratación temprana de los cementos aluminosos (23-26), se obtuvieron muchas curvas ATD de varios cementos hidratados bajo condiciones variables. Las informaciones obtenidas de este estudio tienen interés para las observaciones de otros investigadores que realizaron determinaciones sobre el grado de conversión. A continuación discutimos los diversos problemas encontrados en la interpretación de estas curvas.

Una curva de análisis térmico, representativa para el cemento aluminoso hidratado, muestra la mayoría de los hidratos probables en la figura 3. La ordenada varía según la técnica utilizada, pero el aspecto general de la curva no cambia drásticamente, mientras los endotérmicos (ATD y DSC) y las pérdidas en masa (DTG) descienden [siguiendo las instrucciones de la International Confederation for Thermal Analisis (27)]. En la práctica, o uno u otro, o bien ambos dobletes principales (entre 60 y $170^{\circ} \mathrm{C}$ y entre 260 y $330^{\circ} \mathrm{C}$ ), pueden aparecer como picos aislados, y es posible que los picos pequeños $\left(170-250^{\circ} \mathrm{C}\right)$ no se observen. Esto es una regla antes que una diffraction (XRD), the peaks are not readily suitable for quantitative determination. Preferred orientation can occur with hexagonal phases such as $\mathrm{CAH}_{10}$ and also the hydrates may not be entirely crystalline, especially at the early stages of hydration. Also there are certain phases, which occur which are amorphous by nature, e.g. the gel phases and the presence of these will not be detected by XRD. Therefore, the use of thermal analysis techniques is very important in the study of cements as it gives information as to the hydrate phases present in the early stages of hydration, when this may not be possible from $X R D$. However, comparison of the thermal analysis curve with complementary data from an additional technique (usually XRD) allows a clearer, more accurate interpretation of the trace to be made as some anomalies do occur.

Various methods of thermal analysis, namely differential thermal analysis (DTA), differential scanning calorimetry (DSC) and derivative thermogravimetry (DTG), have been applied to determine the degree of conversion, $\alpha$, and so allow the integrity of the structure to be assessed. These techniques are well explained in standard textbooks on thermal analysis such as those by Wendlandt (19), Daniels (20) and Dodd and Tonge (21), who include a case history concerning the application of thermal methods to the determination of the degree of conversion. Recommendations for the testing of concrete made from calcium aluminate cement by thermal methods is discussed in a report (22) issued by the Thermal Methods Group of the Royal Society for Chemistry.

As part of a thorough investigation of the setting behaviour and early hydration of calcium aluminate cements (23-26), many DTA curves were obtained from a variety of cements hydrated under varying conditions. Information obtained from this study has relevance to observations by other workers who have carried out determinations on the degree of conversion. The various problems which were encountered in interpretation of these traces are therefore discussed below.

An idealised thermal analysis trace for hydrated calcium aluminate cement showing most of the hydrates likely to be formed is shown in Figure 3. The ordinate varies according to the technique used, but the general appearance of the curve does not change dratically, as long as endotherms (DTA and DSC) and losses in mass (DTG) are plotted downwards (following the recommendations of the International Confederation for Thermal Analysis (27). In practice, either or both of the major doublets (between 60 and $170^{\circ} \mathrm{C}$ and 260 and $330^{\circ} \mathrm{C}$ ) may appear as single peaks and the minor peaks $\left(170-250^{\circ} \mathrm{C}\right)$ may not be observed. This is the rule 
Fig. 3.-Curva de análisis térmico teórica para cemento aluminoso hidratado.

Fig. 3.-Idealised thermal analysis curve for hydrated calcium aluminate cement.

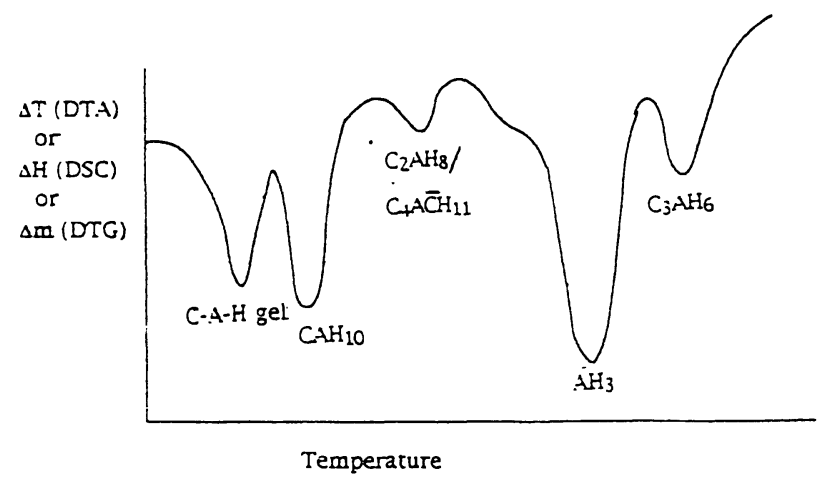

rather than the exception for samples of concrete or mortar, in which the sand acts as a diluent and gives rise to a small, sharp, reversible endotherm at $573^{\circ} \mathrm{C}$ on heating (and endotherm on cooling), due to the reversible polymorphic transformation of $\alpha$-quartz into $\beta$-quartz.

Each of the hydrates present in the cement is indicated by peaks appearing over specific temperature ranges, which are well defined by study of these materials over the years. It must be realised that peak temperatures depend upon procedural variables, including sample mass, heating rate, degree of compaction, gas composition and flow rate and crucible geometry $(19-21,28)$, with the result that data quoted will vary with the apparatus used and the amount of the individual hydrate present in the sample under investigation. To illustrate this point, a sample of Secar 71 cement, which had been hydrated for one week at $30^{\circ} \mathrm{C}$, was analysed under various conditions as illustrated in Figure 4. Three different pieces of apparatus were used; a) a Stanton Redcroft TG 762, b) a Stanton Redcroft DTA 671-B and c) a Stanton Redcroft DTA 67-4. In each case a different sample mass is required, i.e. $10 \mathrm{mg}, 30 \mathrm{mg}$ and $100 \mathrm{mg}$ respectively. Although the curves are af first sight somewhat different, similar conclusions can be drawn from them concerning the phases present. In each curve there is a relatively strong endotherm at a low temperature $\left(66-120^{\circ} \mathrm{C}\right)$ attributable to the presence of the alumina gel phase and some $C A H_{10}$, followed by a weaker endotherm at $133-192^{\circ} \mathrm{C}$, mainly due to $\mathrm{C}_{2} A H_{8}$. (Both $C_{10} H_{10}$ were $C_{2} A H_{8}$ are detected by $X$-ray diffraction). The peak due to gibbsite is very strong in all three curves, accompanied in each case by a shoulder due to $\mathrm{C}_{3} A \mathrm{H}_{6}$ on the high temperature side. It is therefore inevitable that wide ranges of peak temperatures are reported, with variation being particularly large for the "gel" phase and for $C A H_{10}$, but rather less for $C_{2} A H_{8}$, $\mathrm{AH}_{3}$ and $\mathrm{C}_{3} A \mathrm{H}_{6}$. The range of DTA peak temperatures quoted for all of the expected hydrate phases in calcium aluminate cements is 


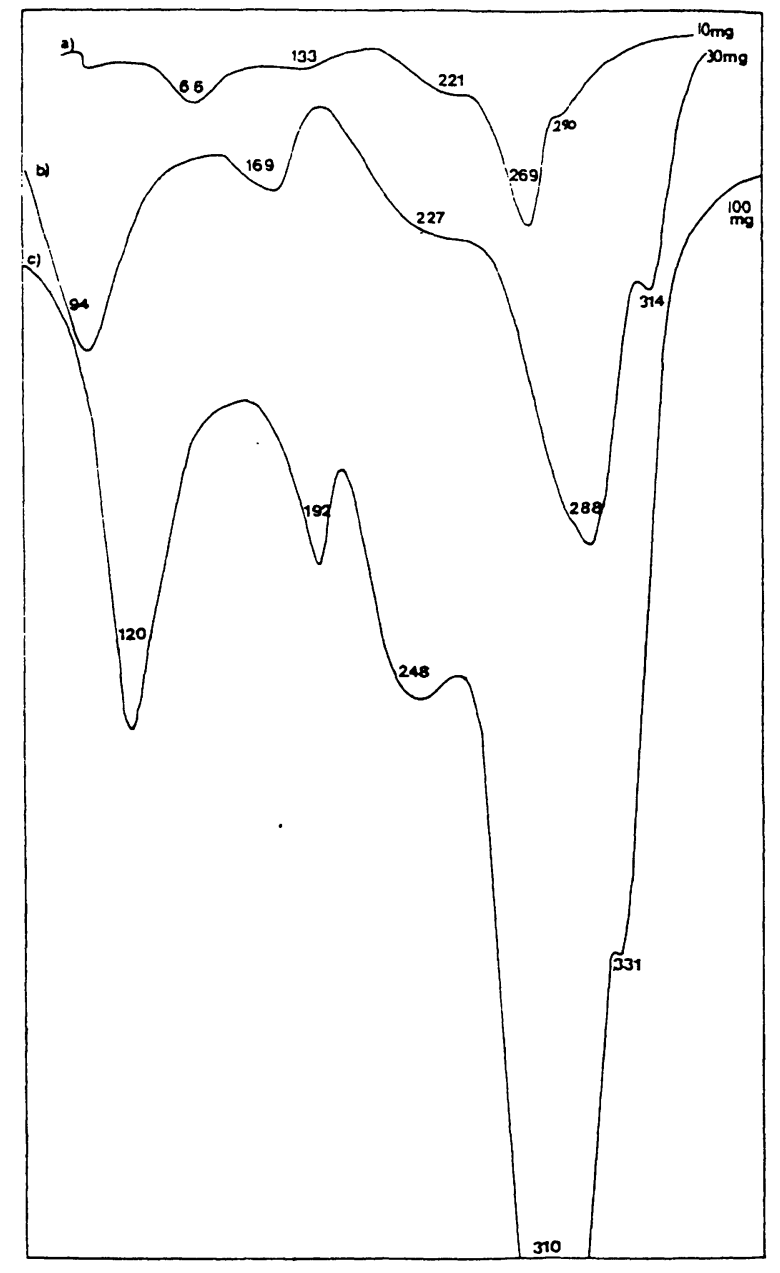

"gel" y para $\mathrm{CAH}_{10}$, pero bastante menos para $\mathrm{C}_{2} \mathrm{AH}_{8}, \mathrm{AH}_{3}$ y $\mathrm{C}_{3} \mathrm{AH}_{6}$. La Tabla 3 muestra los intervalos de temperaturas máximas para todas las fases hidratadas previstas en cementos aluminosos. Si se consulta la literatura se pueden encontrar valores que se salgan de estos intervalos, pero esto puede ocurrir a causa de interpretación errónea o a distintas condiciones experimentales.

Existen claros solapamientos en estos intervalos de temperatura, pero existe un orden de sucesión en la posición de los picos; por ejemplo la fase de gel aparece a la temperatura más baja, sigue $\mathrm{CAH}_{10}$, luego $\mathrm{C}_{2} \mathrm{AH}_{8}, \mathrm{AH}_{3} \mathrm{y}$, finalmente, $\mathrm{C}_{3} \mathrm{AH}_{6}$. Por lo tanto, con experiencia, la interpretación de las curvas ATD de cementos aluminosos hidratados es bastante sencilla. Sin embargo, si se forman otras fases durante el proceso de hidratación, el procedimiento puede llegar a ser mucho más complicado.

Algunos de los problemas que se pueden encontrar en el estudio detallado por ATD de los cementos aluminosos, se discuten a continuación con informaciones adicionales de los datos complementarios de la DRX, donde se considera apropiado para aclarar ciertos puntos.
TABLA 3 TABLE 3

Intervalos de temperatura para varios hidratos de cemento aluminoso

Temperature ranges for the various calcium Aluminate cement hydrates

\begin{tabular}{|l|c|}
\hline $\begin{array}{c}\text { Fase hidratada } \\
\text { (Hydrate phase) }\end{array}$ & $\begin{array}{c}\text { Intervalo de temperatura } \\
\text { (Temperature Range) }\end{array}$ \\
\hline $\mathrm{Gel}$ & $60-130^{\circ} \mathrm{C}$ \\
$\mathrm{CAH}_{10}$ & $100-160^{\circ} \mathrm{C}$ \\
$\mathrm{C}_{2} \mathrm{AH}_{8}$ & $140-200^{\circ} \mathrm{C}$ \\
$\mathrm{AH}_{3}$ & $260-330^{\circ} \mathrm{C}$ \\
$\mathrm{C}_{3} \mathrm{AH}_{6}$ & $290-350^{\circ} \mathrm{C}$ \\
\hline
\end{tabular}

Fig. 4. - Comparación de curvas de análisis térmico obtenidas para la misma muestra en distintas condiciones experimentales.

Fig. 4. - Comparison of thermal analysis curves obtained for the same sample under different experimental conditions.

shown in Table 3. Reference to the literature may show values outside these ranges but these may be due to misinterpretation or to a major variation in experimental conditions.

There are obvious overlaps of these temperature ranges but there is a sequence to the positioning of the peaks as listed, e.g. the gel phase appears at the lowest temperature followed by $\mathrm{CAH}_{10}$, then $C_{2} A H_{8}, A H_{3}$ and finally $C_{3} A H_{6}$. Therefore with experience the interpretation of the DTA curves of hydrated calcium aluminate cements is fairly straightforward. However, if any other phases are formed during the hydration process then the procedure can become much more complicated.

Some of the problems which may be encountered in a detailed study by DTA of calcium aluminate cements are discussed bellow with additional information from the complementary XRD data, where appropriate, for clarification of certain points. 


\section{PARTE EXPERIMENTAL}

Se realizaron estudios de hidratación sobre un intervalo de cementos con el contenido de alúmina oscilando entre 50 y $80 \%$. Se utilizaron cementos Secar 51, Secar 71, Secar 80 , Alcoa CA-14 y Alcoa Ca-25; las composiciones químicas y mineralógicas aparecen en las tablas 1 y 2 .

Las pastas se prepararon mezclando cemento en polvo con agua hervida destilada, que había sido mantenida a temperatura apropiada. La mezcla se realizó a mano; la pasta se vertió en moldes que se taponaron, metieron en bolsas de plástico y luego en baño de agua cuya temperatura se mantenía controlada. Las muestras se retiraron como requería el experimento, y se impidió una posterior hidratación agregando acetona.

Con objeto de preparar las muestras para DRX, el polvo se molió para pasar por un tamiz de $45 \mu \mathrm{m}$ y se utilizó difractómetro Philips PW-1730.

Para el examen por ATD, las muestras se molieron para pasar por un tamiz de $90 \mu \mathrm{m}$ y se utilizó un Stanton Redcroft 67-4. Las condiciones aplicadas fueron: peso de muestra $100 \mathrm{mg}( \pm 1)$, la velocidad de calentamiento de $10^{\circ} \mathrm{C} / \mathrm{min}$ y la velocidad de carta de $5 \mathrm{~mm} / \mathrm{min}$.

\section{RESULTADOS Y DISCUSIÓN}

\section{a) Picos en el intervalo de temperatura de $90-160^{\circ} \mathrm{C}$}

En este intervalo de temperatura se observaron picos debidos a la fase gel y a $\mathrm{CAH}_{10}$. Todos los picos registrados utilizando el ATD 67-4, que se podrian atribuir a la fase gel, se encontraron en el intervalo de $90-120^{\circ} \mathrm{C}$. Como es habitual en todos los picos de análisis térmico había variaciones en la forma, y los picos reales variaban según la cantidad de hidratos presentes. Es probable que la fase gel cambie de naturaleza dependiendo de la temperatura de hidratación, por ejemplo puede cambiar en composición de tipo C-A-H a $12^{\circ} \mathrm{C}$ a un gel aluminoso, $\mathrm{AH}_{n}$ (donde $\mathrm{n}>3$ ) a $30^{\circ} \mathrm{C}$. El otro pico que se espera en este intervalo, es decir, el debido a $\mathrm{CAH}_{10}$, es un poco más difícil de interpretar, puesto que los valores citados en la literatura varían mucho más de lo que se presenta en la tabla 3. Muchas veces los picos clasificados como $\mathrm{CAH}_{10}$ aparecen alrededor de los $100^{\circ} \mathrm{C} \mathrm{y,} \mathrm{por} \mathrm{lo} \mathrm{tanto,} \mathrm{es} \mathrm{más} \mathrm{probable} \mathrm{que} \mathrm{se}$ deban a la fase gel. Cuando la fase gel está también presente, el pico atribuido a $\mathrm{CAH}_{10}$ se encuentra normalmente dentro del intervalo esperado.

En el estudio realizado, en el que se basa este trabajo (24), se ha realizado sólo un número limitado de hidrataciones a temperaturas por

\section{EXPERIMENTAL}

Hydration studies were carried out on a range of cements with a range in alumina content of $50-80 \%$. The cements used were Secar 51 , Secar 71, Secar 80, Alcoa CA-14 and Alcoa CA-25; the chemical and mineralogical compositions are listed in Tables 1 and 2.

Pastes were prepared by mixing the cement powder with boiled, distilled water which had been equilibrated at the appropriate temperature. Mixing was carried out by hand, the paste poured into moulds which were then stoppered, put into a plastic bag and then into a water bath maintained at a controlled temperature. Samples were removed as required and further hydration prevented by quenching with acetone.

To prepare XRD samples the powder was ground tround to pass a $45 \mu \mathrm{m}$ sieve and a Philips $P W-1730$ diffractometer used.

For DTA examination, samples were ground to pass a $90 \mu \mathrm{m}$ sieve and a Stanton Redcroft 67-4 was used. Conditions applied were a sample weight of $100 \mathrm{mg}( \pm$ 1) was used, a heating rate of $10^{\circ} \mathrm{C} / \mathrm{min}$ and a chart speed of $5 \mathrm{~mm} / \mathrm{min}$.

\section{RESULTS AND DISCUSSION}

\section{a) Peaks in the Temperature Region 90-160 ${ }^{\circ} \mathrm{C}$}

In this temperature region it is expected to observe peaks due to the gel phase and to $\mathrm{CAH}_{10}$. All the peaks observed using the DTA 674 which could be attributed to the gel phase fell within the usual range of $90-120^{\circ} \mathrm{C}$. As with all thermal analysis peaks the sharpness and the actual peak temperatures varied with the amount of hydrates present. It is likely that the gel phase changes in nature depending on the hydration temperature, e.g. it may change in composition from a $C-A-H$ type at $12^{\circ} \mathrm{C}$ to an aluminous gel, $A H_{n}$ (where $n>3$ ) at $30^{\circ} \mathrm{C}$. The other peak expected in this region, i.e. $C A H_{10}$, is slightly more difficult to interpret as quoted values in the literature vary much more than the range given in Table 3 above. Often peaks labelled as $\mathrm{CAH}_{10}$ appear at around $100^{\circ} \mathrm{C}$ an are therefore more likely to be due to the gel phase. Where a gel phase is also present then the peak attributed to $\mathrm{CAH}_{10}$ is usually in the expected range.

In the study carried out, on which this work is based (24), only a limited number of hydrations were carried out at temperatures below $20^{\circ} \mathrm{C}$, i.e. 
debajo de $20^{\circ} \mathrm{C}$, es decir las condiciones no eran favorables para la formación de $\mathrm{CAH}_{10}$, así que se detectaron sólo cantidades pequeñas. Sin embargo, una reacción de hidratación realizada a $10^{\circ} \mathrm{C}$ produjo una gráfica ATD mostrando el típico C-A-H gel con solapamiento y los picos de $\mathrm{CAH}_{10}$ (Figura 5). Las barras representan la altura del mayor pico de DRX para cada uno de los hidratos relevantes y se utilizan cuando se requiere la comparación con datos de DRX.

\section{b) Picos en el intervalo de temperatura de $170-230^{\circ} \mathrm{C}$}

Los picos ATD, observados en este intervalo, se pueden interpretar de muchas maneras cuando se consideran los debidos a otras fases que no son las cinco esperadas registradas en la Tabla 3; asignar un pico en este intervalo a $\mathrm{C}_{2} \mathrm{AH}_{8}$ no siempre es correcto, como se comenta más adelante.

\section{Solapamiento de los picos ATD debido a $\mathrm{C}_{2} \mathrm{AH}_{8}$ y carboaluminatos hidratados}

La hidratación de cemento en atmósfera normal inevitablemente conducirá a alguna reacción con

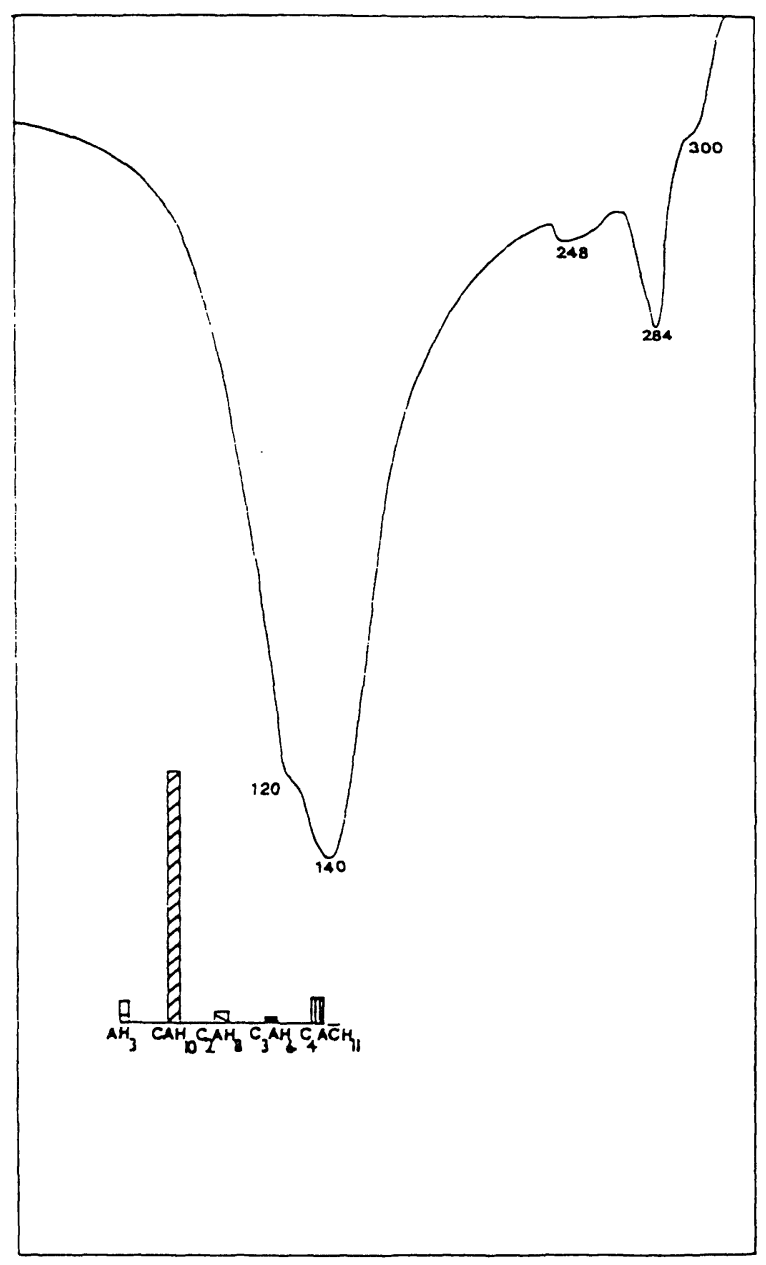

conditions were not favourable for the formation of $\mathrm{CAH}_{10}$ and so only small amounts were detected. However, one hydration reaction carried out at $10^{\circ} \mathrm{C}$ produced a DTA trace showing the typical overlapping $C-A-H$ gel and $C A H_{10}$ peaks.

(Figure 5). The bars shown in addition to the DTA curve represent the height of the major XRD peak for each of the relevant hydrates and are used elsewhere when comparison with XRD data is required.

\section{b) Peaks in the Temperature Region 170- $230^{\circ} \mathrm{C}$}

The DTA peaks observed in this region, when examining hydrated calcium aluminate cements, are open to the most possible interpretations when peaks due to phases other than the expected five listed in Table 3 are considered, i.e. assigning a peak in this temperature region to $\mathrm{C}_{2} \mathrm{AH} \mathrm{H}_{8}$ may not always be correct as discussed bellow.

\section{Overlap of the DTA Peaks Due to $\mathrm{C}_{2} \mathrm{AH}_{8}$ and Carboaluminate Hydrates}

Hydration of the cement in a normal atmosphere will inevitably lead to some reaction with carbon 
fases de dióxido de carbono, y se pueden formar carboaluminatos como el $\mathrm{C}_{4} \mathrm{ACH}{ }_{11}$ donde $\mathrm{C}$ representa $\mathrm{CO}_{2}$. Durante este estudio, varias gráficas de DRX examinadas demostraron mayores cantidades de esta fase que de $\mathrm{C}_{2} \mathrm{AH}_{8}$. La presencia de esta fase está indicada por un pico en el intervalo de $180^{\circ} \mathrm{C}-200^{\circ} \mathrm{C}$ y, como consecuencia, puede ocurrir el solapamiento entre éste y el debido a $\mathrm{C}_{2} \mathrm{AH}_{8}$. La fase que está presente en cantidad más grande formará un pico, pero puede aparecer un "hombro" debido a la otra fase. Frecuentemente, cuando ambas están presentes en aproximadamente una misma proporción, la curva ATD muestra sólo un pico. Como ilustración de esto nos sirve la figura 6 , donde se pueden ver partes destacadas de diversas curvas ATD y las correspondientes alturas de picos de $\mathrm{C}_{2} \mathrm{AH}_{8}$ y $\mathrm{C}_{4} A \mathrm{ACH}_{11}$. (Las barras que representan los picos más intensos de DRX se refieren a $\mathrm{C}_{2} \mathrm{AH}_{8}$ a la izquierda y $\mathrm{C}_{4} \mathrm{ACH}_{11}$ a la derecha). Aquí están incluidas las curvas de pastas a las que se había añadido $\mathrm{CaCO}_{3}$ a propósito para provocar la formación de $\mathrm{C}_{4} A \mathrm{ACH}_{11}$. Esto demuestra claramente la semejanza entre estos dos picos de ATD y el efecto de las cantidades relativas de cada fase. Por eso antes de asignar un pico en este intervalo a $\mathrm{C}_{2} \mathrm{AH}_{8}$, se debe considerar qué fases se pueden esperar o que ya estén presentes según demostró DRX. Cuando están presentes grandes cantidades de gel C-A-H ó $\mathrm{CAH}_{10}$ el pico o los picos que se deben a pequeñas cantidades de $\mathrm{C}_{2} \mathrm{AH}_{8}$ y $\mathrm{C}_{4} \mathrm{ACH}_{11}$ pueden encontrarse mutuamente interferidos, como es el caso en la figura 5. El uso de DRX como un método complementario indicó la presencia de pequeñas cantidades de ambas fases, aunque no se veía ningún hombro en la curva ATD.

\section{Posición del pico debida a $\mathrm{C}_{4} \mathrm{AH}_{13}$}

Otro problema que se encontró en este intervalo de temperatura fue cuando se añadió cloruro de litio al cemento. El uso de sales que contienen litio causa una espectacular aceleración del tiempo de fraguado $(29,30)$, y el estudio ATD y DRX de los hidratos formados bajo estas condiciones (30) se realizó en un intento de aclarar el mecanismo. La presencia de una cantidad significativa de $\mathrm{C}_{4} \mathrm{AH}_{13}$ se detectó por DRX; es una fase que se asocia normalmente con los productos de hidratación de cemento portland antes que de cementos aluminosos. El examen ATD de la pasta de cemento mostró un pico fuerte en el intervalo de $180^{\circ} \mathrm{C}-200^{\circ} \mathrm{C}$ que se debe atribuir principalmente al $\mathrm{C}_{4} \mathrm{AH}_{13}$, puesto que en la DRX se vió poco de $\mathrm{C}_{2} \mathrm{AH}_{\mathrm{B}}$ ó $\mathrm{C}_{4} \mathrm{ACH}_{11}$. Esto ilustra una vez más el solapamiento por los esperados intervalos de temperatura de ATD. dioxide and carboaluminate phases such as $\mathrm{C}_{4} A C \mathrm{H}_{11}$ may be formed where $C$ represents $\mathrm{CO}_{2}$. (For example $\mathrm{CC}=\mathrm{CaO} . \mathrm{CO}_{2}$ or $\mathrm{CaCO}_{3}$ ). During this study several of the XRD traces examined showed this phase to be present, often in larger quantities than $C_{z} A H_{s}$. The presence of this phase is indicated by a DTA peak in the region of $180^{\circ} \mathrm{C}-200^{\circ} \mathrm{C}$ and consequently overlap between this peak and that due to $\mathrm{C}_{2} A H_{8}$ can occur. The phase which is present in the larger amount will form the peak but a shoulder may be seen due to the other phase. Often when both phases are present to about the same extent (as determined by XRD), the DTA curve shows only a single peak. To illustrate these points the relevant parts of a series of DTA curves and corresponding XRD peak heights of $\mathrm{C}_{2} A \mathrm{H}_{8}$ and $C_{4} A C H_{11}$ are shown in Figure 6 . (The bars representing the XRD peak heights refer to $\mathrm{C}_{2} A H_{8}$ on the left and $C_{4} A C H_{11}$ on the right). Included in this set are traces from pastes to which $\mathrm{CaCO}_{3}$ had been added deliberately to promote the formation of $C_{4} A C H_{11}$. This clearly shows the similarity between these two DTA peaks and the effect of the relative amounts of each phase. Hence before assigning a peak in this region to $C_{2} A H_{8}$, some consideration must be made as to what phases are either expected or are shown to be present by XRD. When a very large amount of C-A-H gel or $C A H_{10}$ are present, the peak(s) due to small amounts of $C_{2} A H_{8}$ and $C_{4} A C H_{11}$ may be overwhelmed, as is the case in Figure 5. The use of XRD as a complementary method indicated the presence of minor amounts of both these phases, although no shoulder was apparent on the DTA curve.

\section{Position of the Peak Due to $\mathrm{C}_{4} \mathrm{AH}_{13}$}

Another problem which was encountered in this temperature region was observed when lithium chloride was added to the cement. The use of lithium containing salts causes a spectacular acceleration of the setting time $(29,30)$ and a DTA and XRD study of the hydrates formed under these conditions (30) was carried out in an attempt to clarify the mechanism. The presence of a significant amount of $\mathrm{C}_{4} \mathrm{AH}_{13}$ was detected by $X R D$, a phase more usually associated with the hydration products of Portland cement rather than calcium aluminate cements. DTA examination of the cement paste showed a strong peak in the $180-200^{\circ} \mathrm{C}$ region which must be mainly attributed to the $C_{4} A H_{13}$ as little evidence of either $C_{2} A H_{8}$ or $C_{4} A C H_{11}$ was seen by $X R D$. This again illustrates an overlap of expected DTA temperature ranges. 


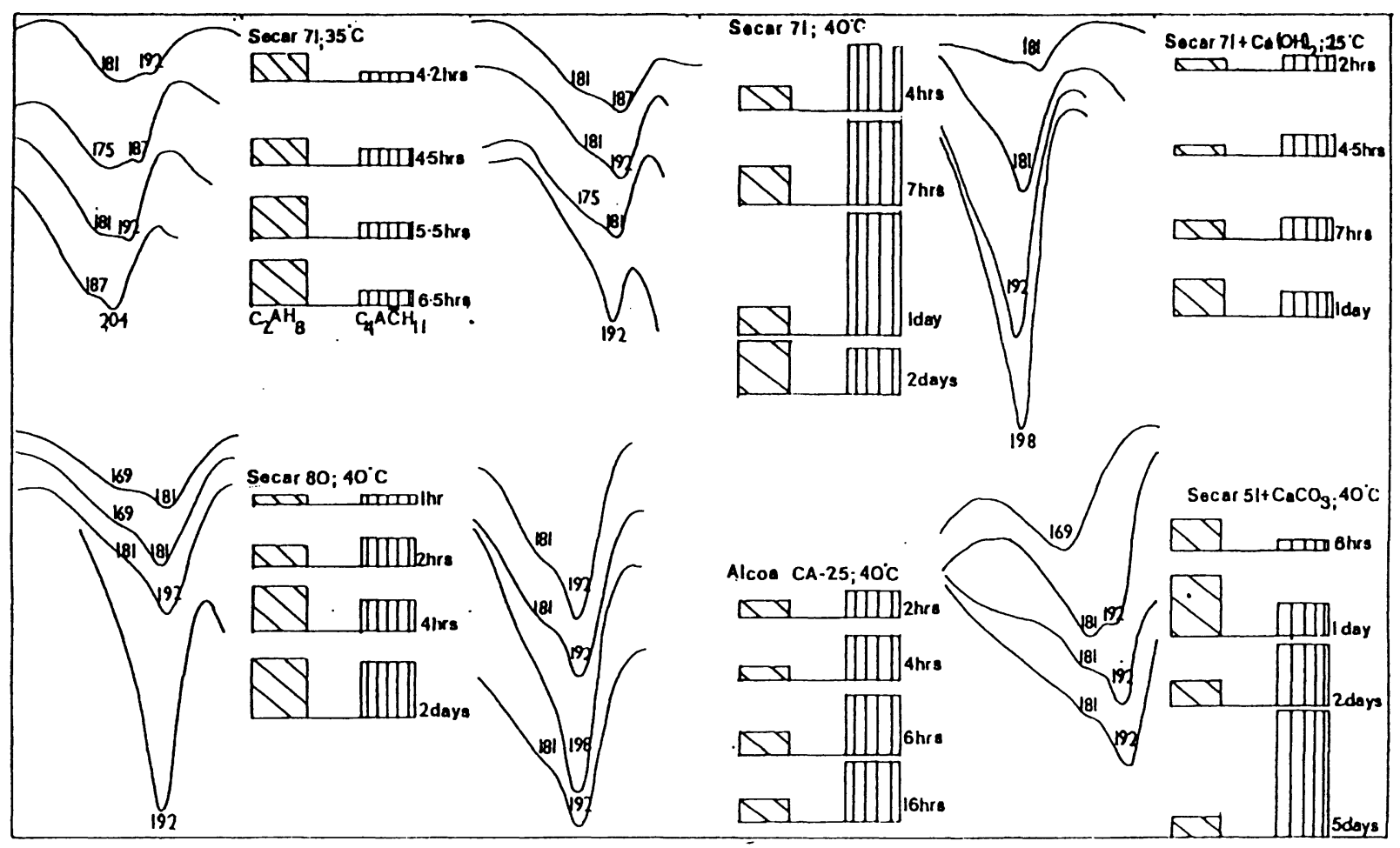

Fig. 6. - Varias curvas ATD (con datos DRX complementarios) que demuestran la presencia de $C_{2} A H_{8}$ y $C_{4} A \bar{C} H_{11}$.

Fig. 6. - Various DTA traces (with complementary $X R D$ data) showing the presence of $C_{2} A H_{8}$ and $C_{8} A \bar{C} H_{11}$.

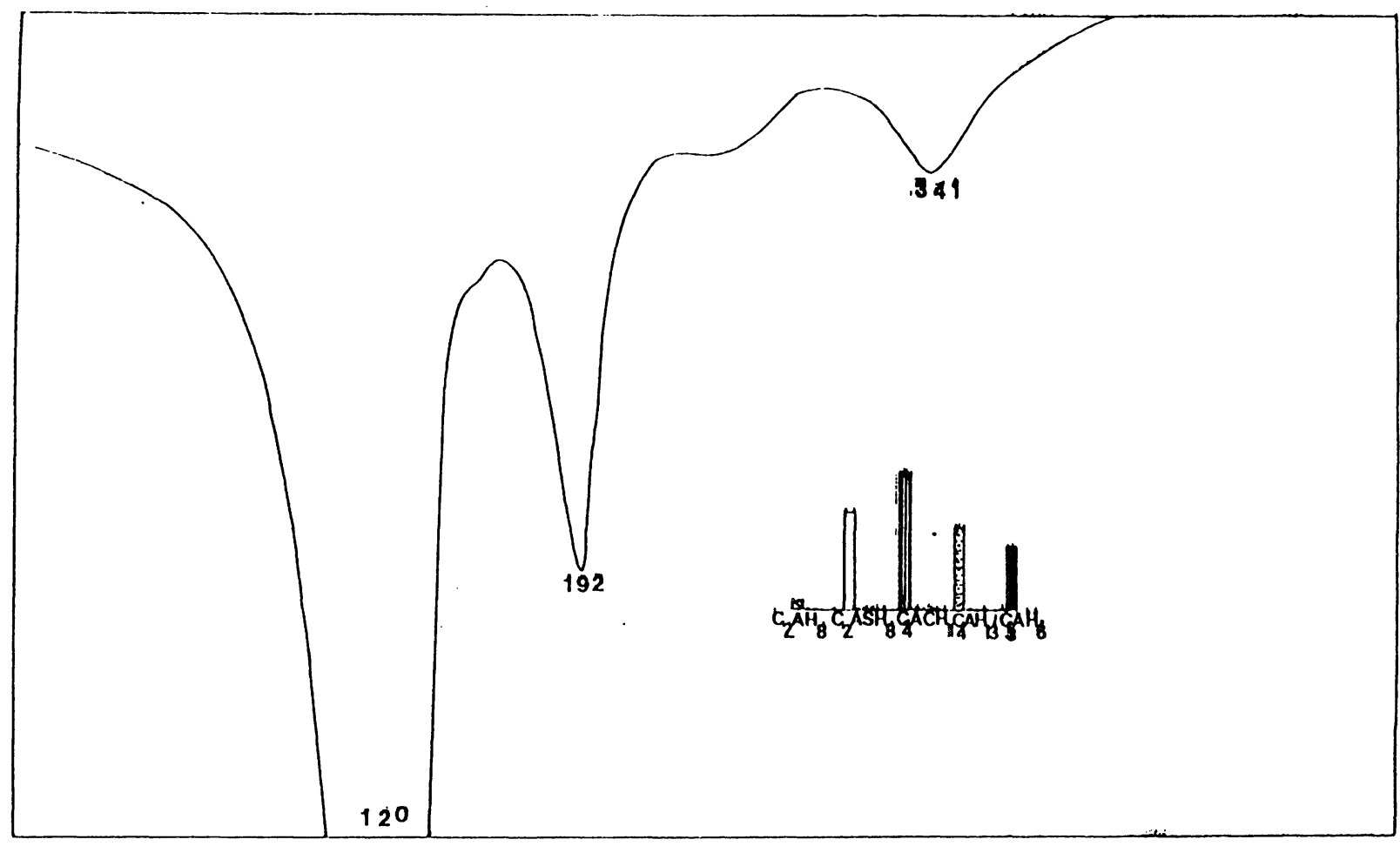

Fig. 7.-Datos ATD y DRX obtenidos de la mezcla de metakaolina e hidróxido de calcio hidratado a $40^{\circ} \mathrm{C}$.

Fig. 7. -DTA and XRD data obtained from the metakaolin/calcium hydroxide mixture hydrated at $40^{\circ} \mathrm{C}$. 


\section{Pico ATD debido a Strätlingita $\left(\mathrm{C}_{2} \mathrm{ASH}_{8}\right)$}

Pueden aparecer más complicaciones en aquel intervalo de temperatura si se utiliza un cemento aluminoso de grado de pureza más bajo. Esto significa que se pueden formar hidratos adicionales debido a la existencia de fases adicionales en el cemento original. La presencia de gehlenita, en particular $\left(C_{2} A S\right)$, conducirá a la formación de $\mathrm{C}_{2} \mathrm{ASH}_{8}$ (gehlenita hidratada 0 strätlingita) mostrando un pico $(5,31-34)$ en el intervalo de temperatura $201-230^{\circ} \mathrm{C}$. Por lo tanto, cuando está presente en cantidades menores, es probable que $\mathrm{C}_{2} \mathrm{ASH}_{8}$ provoque un pico endotérmico en el mismo intervalo de temperatura como los de $\mathrm{C}_{2} \mathrm{AH}_{8}$ y $\mathrm{C}_{4} \mathrm{ACH}_{11}$. Por lo tanto, ¿se debería observar un pico aislado cuando está presente esta fase o un pico combinado asociado con los hidratos anteriormente comentados? Para aclarar la situación, se hidrató una mezcla de metakaolinita + hidróxido cálcico $[\mathrm{MK}: \mathrm{CH}=1$; agua:sólido $=0,75(35)]$ a $40^{\circ} \mathrm{C}$ durante dos semanas para producir una cantidad significativa de $\mathrm{C}_{2} \mathrm{ASH}_{8}$ y $\mathrm{C}_{4} \mathrm{AH}_{13}$. Los datos de DRX mostraron que la pasta obtenida también contenía grandes cantidades de $\mathrm{C}_{4} A \bar{C}_{11}$ y $\mathrm{C}_{3} A \mathrm{H}_{6}$, pero no se detectó $\mathrm{CAH}$. La curva ATD que se obtuvo (Fig. 7) mostró un gran pico de gel a $120^{\circ} \mathrm{C}$ (atribuido a alúmina gel $+\mathrm{C}-\mathrm{S}-\mathrm{H}$ gel) y un pico neto y agudo a $192^{\circ} \mathrm{C}$, lo que indica que las cuatro fases en cuestión $\left(\mathrm{C}_{4} \mathrm{AH}_{13}, \mathrm{C}_{2} \mathrm{ASH}_{8}\right.$ y $\left.\mathrm{C}_{4} \mathrm{ACH}_{11}\right)$ pueden solaparse y contribuir a lo que aparenta ser un único pico ATD.

La aparición de strätlingita no se asocia sólo por el uso de cementos aluminosos de calidad inferior que contienen sílice. Existen aplicaciones frecuentes donde deliberadamente se añaden finos polvos de sílice a las mezclas con base de cemento y al hidratarlas se forma gehlenita hidratada, a costa de $\mathrm{C}_{3} \mathrm{AH}_{6}$. Ejemplos de este uso son adiciones de humo de sílice a las mezclas de prefabricados con bajo contenido de cemento y escoria de horno alto granulada molida/cementos aluminosos. [BRECEM (16-18)].

\section{Los picos ATD de gibsita $\left(\mathrm{AH}_{3}\right)$}

Muchas curvas ATD producidas durante este estudio mostraban picos alrededor de $230^{\circ} \mathrm{C}$ con ninguna señal correspondiente a fases hidratadas, como anteriormente se comentó. Esto era más evidente en las muestras que contenían grandes cantidades de $\mathrm{AH}_{3}$ (gibsita), aumentando el tamaño del pico en $300^{\circ} \mathrm{C}$ al aumentar la cantidad de $\mathrm{AH}_{3}$, lo que sugiere que los picos están relacionados. Así es como Mackenzie (36) describe el ATD pico de gibsita: "La característica principal de gibsita es un fuerte pico endotérmico alrededor de $320^{\circ} \mathrm{C}$ lo que normalmente está acompañado de pequeños efectos endotérmicos alrededor de $250-300^{\circ} \mathrm{C}$ y $525^{\circ} \mathrm{C}$ ".

\section{DTA Peak Due to Strätlingite $\left(\mathrm{C}_{2} \mathrm{ASH}_{8}\right)$}

Further complications can arise in this temperature region if a calcium aluminate cement of lower purity is used as this means that additional hydrates may form due to the occurrence of additional cimentitious phases in the original cement. In particular the presence of gehlenite $\left(C_{2} A S\right.$, where $S$ stands for $\left.\mathrm{SiO}_{2}\right)$ will lead to the formation of $C_{2} A S H_{8}$ (gehlenite hydrate or strätlingite) and this is quoted $(5,31-34)$ as having a DTA peak in the temperature range of 201-203 C. Hence when present in only minor quantities, $C_{2} A S H_{8}$ is likely to give rise to an endothermic peak in the same temperature range as those for $C_{2} A H_{8}$ and $C_{4} A C H_{11}$. Therefore, should a discrete peak be observed when this phase is present or a combined peak in association with the hydrates discussed above? To try to clarify the situation a metakaolinite + + calcium hydroxide mixture (MK: $\mathrm{CH}=1$; water:solid $=0.75$ ) (35) was hydrated at $40^{\circ} \mathrm{C}$ for two weeks to produce a significant amount of $\mathrm{C}_{2} A \mathrm{SH}_{8}$ and $\mathrm{C}_{4} A_{13}$. XRD data showed the resultant paste also contained large quantities of $C_{4} A C H_{11}$ and $C_{3} A H_{6}$ but no $C A H_{10}$ was detected. The DTA trace obtained (Figure 7) showed a large gel peak at $120^{\circ} \mathrm{C}$ (attributed to alumina $\mathrm{gel}+\mathrm{C}-\mathrm{S}-\mathrm{H}$ gel) and one clear, sharp peak at $192^{\circ} \mathrm{C}$, which indicates that the four phases in question $\left(\mathrm{C}_{4} A \mathrm{H}_{13}, \mathrm{C}_{2} A \mathrm{SH}_{8}\right.$ and $\left.\mathrm{C}_{4} A \mathrm{CH}_{11}\right)$ can all overlap and contribute to what is apparently only one DTA peak.

The appearance of strätlingite is not only associated with the use of lower purity calcium aluminate cements containing silica. There are frequent applications where deliberate additions of fine silica (or silica containing) powders are made to cement based mixes and gehlenite hydrate forms on hydration, at the expense of the $\mathrm{C}_{3} A \mathrm{H}_{6}$. Examples of this use are additions of volatilised silica to low cement castables and ground granulated blast furnace slag/calcium aluminate cement mixes [BRECEM (16-18)].

\section{The gibbsite $\left(\mathrm{AH}_{3}\right)$ DTA peaks}

Many of the DTA traces produced during this study showed peaks at about $230^{\circ} \mathrm{C}$ with no correponding evidence of any of the hydrate phases which might be responsible, as discussed above. This was most obvious in those samples containing large amounts of $\mathrm{AH}_{3}$ (gibbsite) and does increase in size as the peak which is attributed to $\mathrm{AH}_{3}$, i.e. that at about $300^{\circ} \mathrm{C}$ suggesting that the peaks are related. Mackenzie (36) describes the DTA peak of gibbsite as follows: "The main characteristic of gibbsite is a strong endothermic peak at about $320^{\circ} \mathrm{C}$ which is usually accompanied by small endothermic effects at about $250-300^{\circ} \mathrm{C}$ and $525^{\circ} \mathrm{C}$ ". 
Las temperaturas citadas aquí son más altas que las observadas en los estudios de cementos hidratados, pero esto es de esperar porque se refieren a una muestra de $\mathrm{AH}_{3}$ puro y se utilizó equipamiento menos moderno que requiere mayor cantidad de muestra. Por lo tanto, una muestra de $\mathrm{AH}_{3}$ sintético (después de diluirla con aluminato precalentado) se registraba con ATD (bajo las mismas condiciones experimentales que antes) para imitar la situación de la mezcla de gibsita más otras fases, como ocurre en la pasta de cemento. La curva que se obtuvo, figura 8 , demostró todos los efectos esperados y el primer endotérmico se situó alrededor de $240^{\circ} \mathrm{C}$. Por eso, cuando el cemento hidratado contiene grandes cantidades de gibsita se debe esperar un pico adicional a temperaturas por encima de $240^{\circ} \mathrm{C}$.

La comparación de los datos de ATD y los de DRX, en muchos de estos cementos hidratados, muestra que el pico ATD a $270-300^{\circ} \mathrm{C}$, es decir, el pico principal de esta fase, frecuentemente indica la presencia de más $\mathrm{AH}_{3}$ que el correspondiente modelo DRX. Esto indica que en las etapas iniciales de hidratación se forman sustanciales cantidades de $\mathrm{AH}_{3}$ amorfo y también algo de $\mathrm{AH}_{3}$ cristalizado, que aumenta con la edad.

\section{c) Identificación de picos ATD en el intervalo $270-340^{\circ} \mathrm{C}$}

En algunas curvas ATD obtenidas durante este estudio, bajo ciertas condiciones de hidratación, se ve un triple pico en la región de $270-340^{\circ} \mathrm{C}$ donde se esperarían sólo dos, es decir, los debidos a $\mathrm{AH}_{3}\left(290^{\circ} \mathrm{C}\right)$ y $\mathrm{C}_{3} \mathrm{AH}_{6}\left(330^{\circ} \mathrm{C}\right)$. A veces existe sólo una sombra de un tercer pico, pero otras veces se han observado tres picos muy marcados. Los sistemas que mostraban este efecto eran: Secar 71 hidratado a $40^{\circ} \mathrm{C}$ y a $50^{\circ} \mathrm{C}$, Secar 51 a $30^{\circ} \mathrm{C}$ y Secar 51 + carbonato de calcio a $40^{\circ} \mathrm{C}$. La presencia de estos picos no está causada por un fenómeno espúreo, puesto que las repeticiones de la muestra demostraban lo mismo. También se ha observado, varias veces, en distintos sistemas de cemento aluminoso y en trabajos de otros autores $(37,38)$.

El ejemplo más claro de los tres picos mostrados en la figura 9 y otros ejemplos están ilustrados en la figura 10. El pico a la temperatura más alta $\left(325-331^{\circ} \mathrm{C}\right)$ a $\mathrm{C}_{3} \mathrm{AH}_{6}$. El otro pico podría parecer el resultado de una fase hidratada metaestable, ya que en los dos ejemplos Secar 71 se ve que el pico "extra" desaparece. El sistema Secar 51 mostró este efecto en un tiempo mucho más largo y las muestras posteriores no se utilizaron para determinar si este pico realmente era transitorio. El estudio de difractogramas de RX no mostraron ninguna prueba de la existencia de una fase "extra" cristalina que justificara el pico adicional ATD, lo que sugiere que dicha fase es amorfa o
The temperatures quoted here are higher than those observed in the hydrated cements studied, but as a sample of pure $\mathrm{AH}_{3}$ is referred to and older equipment requiring a larger sample mass was used, this is to be expected. A sample of synthetic $\mathrm{AH}_{3}$ (after dilution with pre-fired alumina) was therefore run on the DTA (under the same experimental conditions as before) to mimic the situation of a mixture of gibbsite plus other phases as occurs in the cement paste. The resulting trece, figure 8, showed all the expected effects and places the first endotherm at about $240^{\circ} \mathrm{C}$. Hence when large amounts of gibbsite are present in the hydrated cement the appearance of an additional peak at temperatures up to $240^{\circ} \mathrm{C}$ must be expected.

Comparison of both DTA and XRD data for many of these hydrated cements shows that the DTA peak at $270-300^{\circ} \mathrm{C}$, i.e. the main peak for this pase, frequently suggests more $\mathrm{AH}_{3}$ to be present than the corresponding XRD pattern. This indicates that in the initial stages of hydration, substantial amounts of amorphous $\mathrm{AH}_{3}$ are formed as well as some crystalline $\mathrm{AH}_{3}$, which increases on ageing.

\section{c) Identification of DTA peaks in the region $270-340^{\circ} \mathrm{C}$}

In some of the DTA traces obtained during this study, under certain hydration conditions, a triple peak is seen in the region $270-340^{\circ} \mathrm{C}$ where only two would be expected, i.e. those due to $\mathrm{AH}_{3}$ $\left(290^{\circ} \mathrm{C}\right)$ and $\mathrm{C}_{3} \mathrm{AH}_{6}\left(330^{\circ} \mathrm{C}\right)$. Sometimes there is only a suggestion of a third peak but occasionally three very distinct peaks have been observed. Systems showing this effect were Secar 71 hydrated at $40^{\circ} \mathrm{C}$ and at $50^{\circ} \mathrm{C}$, Secar 51 at $30^{\circ} \mathrm{C}$ and a Secar 51 + calcium carbonate system at $40^{\circ} \mathrm{C}$. The presence of these peaks is not a spurious effect as repeats of the sample stil showed the same effect. Additionally it has been observed several times, in different calcium aluminate cement systems including work by other authors $(37,38)$.

The clearest example of the three peaks is shown in Figure 9 and further examples are illustrated in Figure 10. The peak at the lower temperature $\left(290-300^{\circ} \mathrm{C}\right)$ can be attributed to $\mathrm{AH}_{3}$ and that at the higher $\left(325-311^{\circ} \mathrm{C}\right)$ to $\mathrm{C}_{3} A \mathrm{H}_{6}$. The other peak would appear to be due to a metastable hydrate phase, as in both the Secar 71 examples the "extra" peak is seen to disappear. The Secar 51 systems showed this effect at a much longer time and later samples were not taken to determine whether or not this peak was indeed transient. Examination of the relevant XRD traces showed no evidence of an extra crystalline phase to account for the additional DTA peak, suggesting 


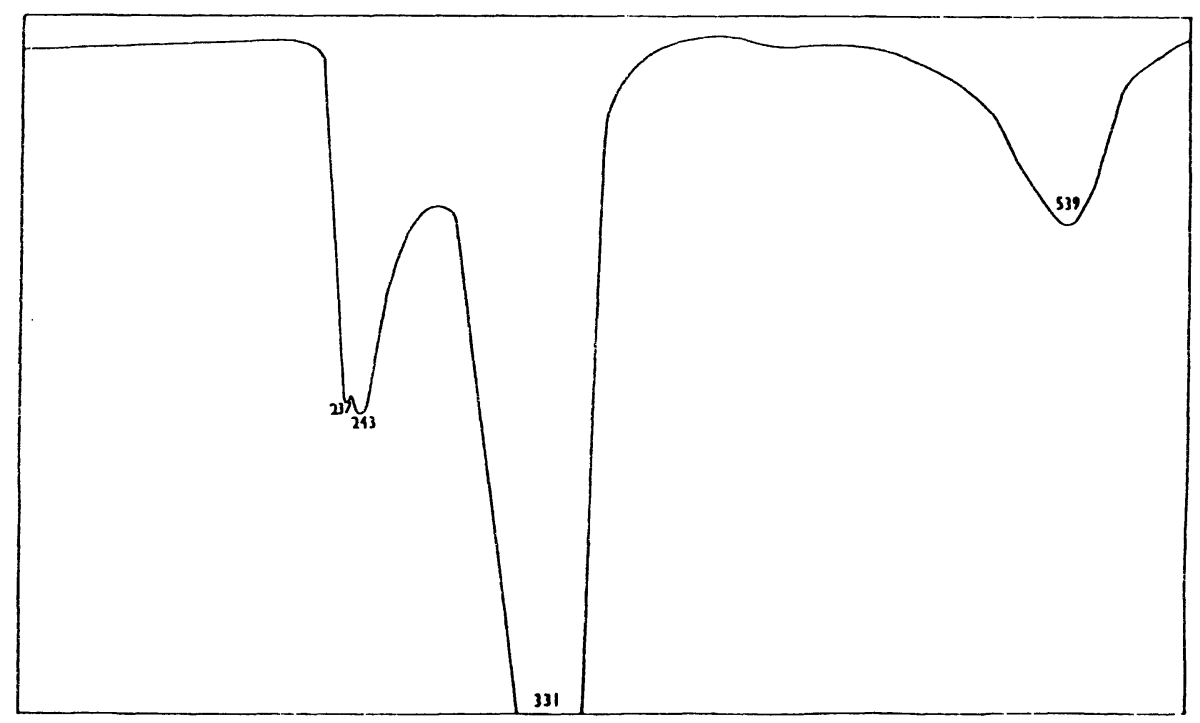

Fig. 8. - Curva $A T D$ obtenida de $A \mathrm{I}(\mathrm{OH})_{3}$ reactivo para análisis y alúmina.

Fig. 8. -DTA traces obtained from Analar grade $\mathrm{Al}(\mathrm{OH})_{3}$ alumina.

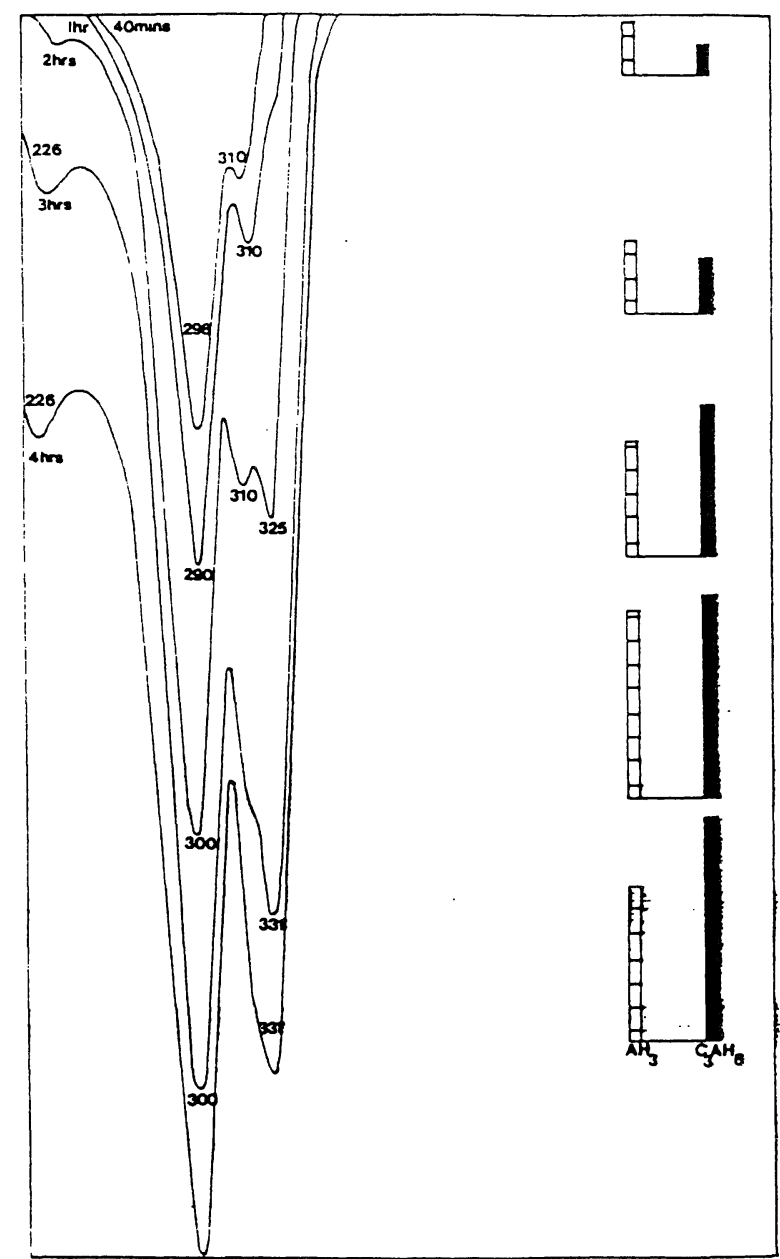

Fig. 9.-Curvas ATD con un triple pico de Secar 71 hidratado a $50^{\circ} \mathrm{C}$ - datos DRX también incluidos.

Fig. 9.-DTA traces of Secar 71 hydrated at $50^{\circ} \mathrm{C}$ showing a triple peak - XRD data also included.

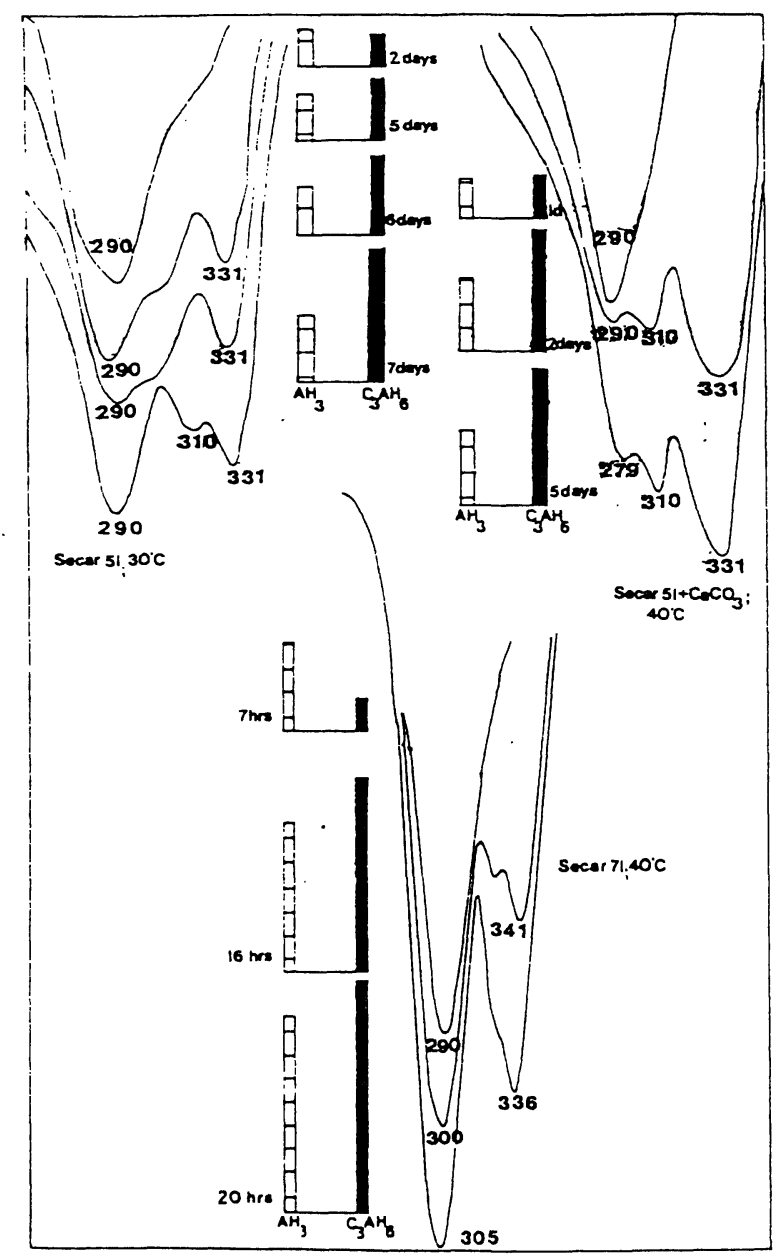

Fig. 10.-Otros ejemplos del triple pico en DRX.

Fig. 10. - Further examples of the triple XRD peak. 
por lo menos poco cristalina.

La discrepancia observada entre el tamaño del pico ATD y la altura del pico DRX para el $\mathrm{AH}_{3}$ ya se ha mencionado, sugiriendo que una cantidad considerable de $\mathrm{AH}_{3}$ que se forma es de naturaleza amorfa. Esto es una observación muy común en todos los sistemas estudiados, es decir ocurre cuando no se ve un tercer pico, así que no resulta adecuado asignar el pico al $\mathrm{AH}_{3}$ amorfo. Otra prueba en contra del $\mathrm{AH}_{3}$ amorfo es el hecho de que el pico adicional se encuentra a una temperatura más alta que el observado en caso del $\mathrm{AH}_{3}$ cristalino, y sería raro para una fase amorfa mostrar una temperatura de pico ATD más alta que la de la fase debida al material cristalino. Además, cuando desaparece el pico ATD extra no aparece el correspondiente aumento del pico $\mathrm{AH}_{3}$ en el difractograma de $\mathrm{RX}$, lo que sería de esperar si el amorfo $\mathrm{AH}_{3}$ fuese cristalizándose a medida que progresaba la reacción de hidratación.

La siguiente posibilidad es que la fase amorfa sea una forma intermedia que ocurre durante la conversión de $\mathrm{C}_{2} \mathrm{AH}_{8}$ a las fases estables $\mathrm{C}_{3} \mathrm{AH}_{6}+\mathrm{AH}_{3}$. El estudio de datos DRX demuestra que la aparición del tercer pico ATD sucede más o menos al mismo tiempo que empieza a disminuirse la cantidad de $\mathrm{C}_{2} \mathrm{AH}_{8}$. Por lo tanto puede existir un producto amorfo interino de la reacción de conversión, es decir "proto$\mathrm{C}_{3} \mathrm{AH}_{6}$ ", cuya presencia está indicada por un pico ATD alrededor de $325^{\circ} \mathrm{C}$. Pueden existir otras posibles explicaciones, por ejemplo imiscibilidad en la solución sólida de $\mathrm{C}_{3} \mathrm{AH}_{6}-\mathrm{C}_{3} \mathrm{AS}_{3}$ (39), quizás en el caso de Secar 51, pero cualquiera que sea la naturaleza de la causa la aparición de este tercer pico no se puede negar, aunque está claro que en el pasado se ignoró.

\section{d) Determinación del grado de conversión}

La interpretación de las curvas ATD de cementos aluminosos deben pues hacerse con cuidado y se debe considerar la posibilidad de otras fases, aparte de aquéllas normalmente separadas. También se ha demostrado que es casi imposible separar los picos solapados en sus componentes y cómo la cantidad de un hidrato particular es proporcional al área del pico, esto claramente presenta un problema cuando se intenta determinar el grado de conversión de cemento. El método que se utiliza depende de la altura de ciertos picos, lo que determina una escala de conversión empírica (más que real).

El principio en el que se base el método consiste en comparar las alturas de los picos debidos a $\mathrm{CAH}_{10}$ y $\mathrm{AH}_{3}$ con los obtenidos de las muestras estándar con el grado de conversión conocido, conducidos en los mismos aparatos bajo las that the phase in question is amorphous or at least poorly crystalline.

The observed discrepancy between the size of the DTA peak and the height of the XRD peak for $\mathrm{AH}_{3}$ has already been mentioned, suggesting that a substantial amount of the $\mathrm{AH}_{3}$ formed is amorphous in nature. This is a very common observation in all the systems studies, i.e. it occurs when no third peak is seen and so assigning the peak to amorphous $\mathrm{AH}_{3}$ is not a suitable answer. Further evidence against amorphous $\mathrm{AH}_{3}$ is the fact that the additional peak is at a higher temperature than that observed for crystalline $\mathrm{AH}_{3}$ and it would be unusual for an amorphous phase to show a higher DTA peak temperature than that due to the crystalline material. Additionally, as the extra DTA peak disappears, there is not a correponding increase in the XRD pattern of $\mathrm{AH}_{3}$ which would be expected if amorphous $\mathrm{AH}_{3}$ was crystallising as the hydration reaction progressed.

The next possibility is that the amorphous phase is an intermediate form occurring during the conversion of $\mathrm{C}_{2} A \mathrm{H}_{8}$ to the stable $\mathrm{C}_{3} A \mathrm{H}_{6}+\mathrm{AH}_{3}$ phases. Examination of the XRD data shows that the appearance of the third DTA peak appears at about the time that the amount of $\mathrm{C}_{2} \mathrm{AH}_{8}$ begins to decrease. Therefore, there may be an interim amorphous product of the conversion reaction, i.e. a "proto- $\mathrm{C}_{3} \mathrm{AH}_{6}$ ", the presence of which is indicated by a DTA peak in the region of $325^{\circ} \mathrm{C}$. There may be other possible explanations e.g. immiscibility in the $\mathrm{C}_{3} A \mathrm{H}_{6}-\mathrm{C}_{3} A S_{3}$ solid solution (39) perhaps in the case of Secar 51, but whatever the nature of the cause, the appearance of this third peak cannot be denied although in the past it has obviously been ignored.

\section{d) Determination of the degree of conversion}

The interpretation of DTA traces of calcium aluminate cements therefore must be done with care and the possibility of additional phases to those normally expected must be considered. It has also been shown that it is almost impossible to resolve overlapping peaks into their constituents and as the amount of a particular hydrate is proportional to the area under the peak this obviously presents a problem when trying to determine the degree of conversion of a cement. The method used depends instead upon the height of certain peaks and as such is determining an empirical (rather than an actual) scale of conversion.

The principle on which the method is based is to compare the heigts of the peaks due to $\mathrm{CAH}_{10}$ and $\mathrm{AH}_{3}$ with those obtained from standard samples of known degree of conversion, run on the same apparatus under the same experimental 
mismas condiciones experimentales.

Originalmente, el grado de conversión, $D_{c}$, fue definido $(2,22)$ como

$$
D_{c}=\frac{C_{3} A_{6} \times 100}{C_{3} A H_{6}+\mathrm{CAH}_{10}}
$$

No obstante, durante una exposición al aire es probable que la fase $\mathrm{C}_{3} \mathrm{AH}_{10}$ llegue a carbonatarse, en parte, reduciendo de ese modo la cantidad aparente de esta fase determinada a través del análisis térmico y conduciendo a un valor más bajo de $D_{c}$ del real. Ya que $\mathrm{AH}_{3}$ no se carbonata, las recomendaciones utilizadas en Reino Unido (22) describen $D_{c}$ como

$$
D_{c}=\frac{\mathrm{AH}_{3} \times 100}{\mathrm{AH}_{3}+\mathrm{CAH}_{10}}
$$

Puesto que resulta tan difícil determinar el área del pico debido a estos hidratos, la constante empírica, $\alpha$, se determina de la ecuación

$$
\alpha=\frac{100}{1+K \cdot h_{1} / h_{2}}
$$

donde $h_{1}$ es la altura del pico $\mathrm{CAH}_{10}$ y $h_{2}$ es la altura del pico $\mathrm{AH}_{3}$. K es una constante instrumental, que varía mucho según los diferentes equipos y debe determinarse con previa calibración. Puesto que es difícil sintetizar muestras puras de aluminatos de calcio hidratados mutuamente libres (y mantenerlos en esa condición sin alterar), la determinación de $\mathrm{K}$ no es una tarea sencilla. Además, es probable que el mismo $\mathrm{K}$ varíe con el grado de conversión.

El ensayo está abierto a críticas en otros aspectos. Ya que los dobletes habitualmente no están separados en las muestras obtenidas de morteros y hormigones, $h_{1}$ es la altura máxima del desplazamiento máximo desde la línea base, entre 100 y $200^{\circ} \mathrm{C}$, y pueden contener la fase gel C-A-H y también $\mathrm{CAH}_{10}$. Asimismo $h_{2}$ es la altura del pico observada alrededor de $300^{\circ} \mathrm{C}$ y puede ser afectada por la presencia tanto de $\mathrm{AH}_{3}$ como de $\mathrm{C}_{3} \mathrm{AH}_{6}$. En la mayoría de las muestras el $\mathrm{AH}_{3}$ puede haber sido formado no sólo por conversión, sino también por envejecimiento de geles $\mathrm{C}-\mathrm{A}-\mathrm{H}$ y $\mathrm{AH}_{n} \circ$ por hidratación de cualquier $\mathrm{CA}_{2}$ presente.

\footnotetext{
Al parecer, el método determina el grado de conversión válido hasta $\pm 5 \%$, $\theta$ incluso la reproducibilidad con un único instrumento puede ser mejor que ésta. Sin embargo, cuando se comparan los resultados procedentes de diferentes laboratorios que utilizan equipamiento diferente, la dispersión de los resultados puede ser mayor que $\pm 5 \%$. Por esta razón cualquier estudio de la conversión en una viga determinada, con el tiempo que precisa sacar
}

conditions. Originally the degree of conversion, $D_{c}$, was defined $(2,22)$ as

$$
D_{c}=\frac{\text { amount of } \mathrm{C}_{3} A \mathrm{H}_{6} \times 100}{\text { amount of } \mathrm{C}_{3} \mathrm{AH} \mathrm{H}_{6}+\text { amount of } \mathrm{CAH}_{10}}
$$

During natural exposure, however, the $\mathrm{C}_{3} \mathrm{AH}_{6}$ phase is likely to become partly carbonated, thus reducing the apparent amount of this phase determined by thermal analysis and leading to a lower value of $D_{c}$ than is actually the case. Since $\mathrm{AH}_{3}$ is not subjet to carbonation, the recommendations used in the U.K. (22) define $D_{c}$ as

$$
D_{c}=\frac{\text { amount of } \mathrm{AH}_{3} \times 100}{\text { amount of } \mathrm{AH}_{3}+\text { amount of } \mathrm{CAH}_{10}}
$$

Since the area under the peak due to these hydrates is so difficult to determine, the empirical constant, $\alpha$, is determined from the equation

$$
\alpha=\frac{100}{1+K \cdot h_{1} / h_{2}}
$$

where $h_{1}$ is the peak height of the $C A H_{10}$ peak and $h_{2}$ is the height of the $\mathrm{AH}_{3}$ peak. $\mathrm{K}$ is an instrumental constant, which varies extensively for different equipment and must be determined by the use of calibration standard. Since it is difficult to synthesize pure samples of calcium aluminate hydrates free from one onother (and to maintain them in unchanged condition), determination of $K$ is not a trivial task. Moreover, it is likely that $K$ itself varies with the degree of conversion.

The test is open to criticism in other respects. Because the doublets are not usually resolved in specimens obtained from mortars and concretes, $h_{1}$ is the height of the maximum displacement from the baseline between 100 and $200^{\circ} \mathrm{C}$ and may include a significant contribution from the $C$-A-H gel phase as well as from $C_{10}$. Similarly $h_{2}$ is the height of the peak observed around $300^{\circ} \mathrm{C}$ and may be effect by the presence of both $\mathrm{AH}_{3}$ and $\mathrm{C}_{3} \mathrm{AH}_{6}$. In most specimens $\mathrm{AH}_{3}$ may have been formed not only by conversion, but also by ageing of $\mathrm{C}-\mathrm{A}-\mathrm{H}$ and $\mathrm{AH} \mathrm{H}_{n}$ gels, or by hydration of any $C A_{2}$ present.

It is claimed that the method gives a degree of conversion valid to $\pm 5 \%$ and indeed the reproducibility on a single instrument may be better than this. However, when results are compared from different laboratories using different equipment, the scatter of results may be greater than $\pm 5 \%$. For this reason any monitoring of the extent of conversion of a particular beam with time involving the taking of samples every few months should be carried out 
diversas muestras al cabo de varios meses, debería realizarse con el mismo instrumento utilizando la misma cantidad de muestra. A pesar de estas limitaciones, el método ha sido ampliamente utilizado y proporciona informaciones que no se obtienen con facilidad a través de otros métodos de ensayos no destructivos. Si se encuentra que la viga tiene un alto grado de conversión ( $\alpha>80 \%$ ) y todavía sigue en buen estado, entonces no es probable que se deteriore más, salvo que la ataquen sustancias químicas como álcalis o sulfatos. Los métodos térmicos también son adecuados para detectar la presencia de yeso (habitualmente presente por tomar muestras después de la perforación hecha a través de cubierta de enlucido) o ettringita (formada por el ataque de sulfato).

Los problemas asociados con la conversión de cementos aluminosos significan que, actualmente, tienen uso limitado en la industria de construcción. No obstante, existen varias situaciones donde ciertas propiedades de estos cementos pueden explotarse (como, por ejemplo, rápido desarrollo de resistencia); se utilizan aplicando estos cementos como material de reparación cuando se requiere una rápida vuelta al servicio. La velocidad de calentamiento también lo hace apropiado para hormigonar en un clima frío o en situaciones que precisan refrigeración. Además, este cemento es resistente a sulfatos, ya que fue originalmente desarrollado para este fin. Finalmente, el uso más amplio de cementos aluminosos es debido a sus excelentes propiedades refractarias, especialmente en la producción de materiales refractarios prefabricados. on the same instrument using the same sample mass. In spite of these limitations, the method has been widely used and provides information not readily obtained by other nondestructive test methods. If a beam is found to be highly converted ( $\alpha>80 \%$ ) and is still in sound condition, then it is unlikely to deteriorate further unless attacked by chemicals such as alkali or sulphate ions. Thermal methods also provide a sensitive test for the presence of gypsum (usually present after drilling through a plaster covering) or ettringite (formed by sulphate attack).

The problems associated with the conversion reactions of calcium aluminate cements mean that at present it has limited use in the construction industry. There are, however, several situations where certain properties of these cements can be exploited, e.g. the rapid strength development is utilised by using these cements as repair materials where a rapid return to service is required. Also, the rate of heat evolution makes it suitable for concreting in cold weather or in industrial situations involving refrigeration. In addition there is the sulphate resistance of this cement, the property for which it was originally developed. Finally, the largest use for calcium aluminate cements exploits their excellent refractory properties, especially in the production of castable refractory materials.

\section{REFERENCIAS}

\section{REFERENCES}

(1) ROBSON, T. D.: "High alumina cements and concretes", London Contractors Record., 1962.

(2) MIDGLEY, H. G. and MIDGLEY, A.: The conversion of high alumina cement., Mag. Concr. Res., 27, (pp. 59-77), 1975.

(3) PARKER, K. M. and SHARP, J. H.: Refractory calcium aluminate cements - Review, Trans. Brit. Cer. Soc. 81, (pp. 35-42), 1982.

(4) GEORGE, C. M.: Industrial aluminous cement., in "Structure and performance of cements.", Ed. P. Barnes, 1983.

(5) LEA, F. M.: "The chemistry of cement and concrete", 3rd Ed., Edward Arnold Limited, London., 1970.

(6) NEVILLE, A. M.: "High alumina cement concrete", The Construction Press, Lancaster., 1975.

(7) TAYLOR, H. F. W.: "Cement Chemistry", Academic Press, London, 1990.

(8) MIDGLEY, H. G.: The composition and possible structure of the quaternary phase in high alumina cement and its relation to other phases in the system CaO-MgO-Al $\mathrm{O}_{3}$, Trans. Brit. Ceram. Soc., 67, (pp. 1-14), 1968.

(9) MIDGLEY, H. G.: The mineralogy of set high alumina cement. Trans. Brit. Ceram. Soc. 66, (pp. 161-187), 1967

(10) EDMONDS, R. N. and MAJUMDAR, A. J.: The hydration of monocalcium aluminate at different temperatures., Cem. Concr. Res., 18, (pp. 311-320), 1988. 
(11) PAYNE, D. R. and SHARP, J. H.: The nature of the gel phase in calcium aluminate cements., The microstructure and chemistry of cement and concrete, abstract at Inst of Ceramics Conference., University of Aberdeen, 1989.

(12) RASHID, S., BARNES, P. and TURRILLAS, X.: The rapid conversion of calcium aluminate cement hydrates as revealed by synchatron energy dispersive diffraction., Adv. Cem. Res., 4, (pp. 61-67), 1991/1992.

(13) BATE, S. C. C.: Report on the failure of roof beams at Sir Johns Cass's Foundation and Red Coat Church of England School, Stepney., Building Research Establishment Current Paper, CP 58/74, 1974.

(14) MIDGLEY, H. G.: High alumina cement in construction - A future based on experience., Calcium Aluminate Cements., Queen Mary and Westfield College, University of London, Ed. R. J. Mangabhai, E \& F.N. Spon, London, 1990.

(15) BATE, S. C. C.: High alumina cement concrete-asesment from laboratory and field studies., The Structural Engineer, 58A, (pp. 388-394), 1980.

(16) MAJUMDAR, A. J., EDMONDS, R. N. and SINGH, B.: Hydration of Secar 71 aluminous cement in the presence of granulated blast furnace slag., Cem. Concr. Res., 20, (pp. 7-14), 1990.

(17) MAJUNDAR, A. J., EDMONDS, R. N. and SINGH, B.: Hydration of mixtures of "ciment fondu" aluminous cement and granulated blast furnace slag., Cem. Concr. Res., 20, (pp. 197-208), 1990.

(18) MAJUMDAR, A. J., EDMONDS, R. N. and SINGH, B.: Hydration of calcium aluminates in presence of granulated blast furnace slag. Calcium Aluminate Cements, Queen Mary and Westfield College, University of London, Ed. R. J. Mangabhai, E. \& F. N. Spon. London., 1990.

(19) WENDLANDT, W. W.: "Thermal Analysis", 3rd Ed., Wiley-Interscience, New York, 1986.

(20) DANIELS, T. D.: "Thermal Analysis", Kogan Page, Lonon, 1973.

(21) DODD, J. W. and TONGE, K. H.: "Thermal Methods", John Wiley and Sons, Chitchester, 1987.

(22) WILBURN, F. W., KEATTCH, C. J. MIDGLEY, H. G. and CHARSLELY, E. L.: Recommendations for the testing of high alumina cement concrete samples by thermoanalytical techniques. Thermal Methods Group, Analytical Division of the Chemical Society, London, 1975.

(23) BUSHNELL-WATSON, S. M. and SHARP, J. H.: The effect of temperature upon the setting behaviour of refractory calcium aluminate cements., Cem. Concr. Res., 16, (pp. 875-884), 1986.

(24) BUSHNELL-WATSON, S. M.: The effect of temperature on the setting behaviour of refractory calcium aluminate cements. Ph. D. Thesis, University of Sheffield, 1987.

(25) BUSHNELL-WATSON, S. M. and SHARP, J. H.: Further studies on the effect of temperature upon the setting behaviour of refractory calcium aluminate cements. Cem. Concr. Res., 20, (pp. 623-635), 1990.

(26) BUSHNELL-WATSON, S. M. and SHARP, J. H.: On the cause of the anomalous setting behaviour with respect to temperature of calcium aluminate cements. Cem. Concr. Res., 20, (pp. 677-686), 1990.

(27) MACKENZIE, R. C., TALANTA: 16, (pp. 1.227-1.230), 1969.

(28) WILBURN, F. W., SHARP, J. H. TINSLY, D. M. and McINTOSH, R. M.: J. Thermal Analysis, 37, (pp. 2.003-2.019; Ibid, 2.021 2.029), 1991.

(29) RODGER, S. A. and DOUBLE, D. D.: The chemistry of hydration of high alumina cement in the presence of accelerating and retarding admixtures. Cem. Concr. Res., 14, (pp. 73-82), 1984.

(30) SHARP, J. H., BUSHNELL-WATSON, S. M., PAYNE, D. R. and WARD, P. A.: The effect of admixtures on the hydration of refractory calcium aluminate cements. Calcium aluminate cement, Queen Mary and Westfield College, University of London, Ed. R. J. Mangabhai, E. \& F.N. Spon, London, 1990.

(31) MIDGLEY, H. G. and RAO, P. B.: Formation of strätlingite, $2 \mathrm{CaO} \cdot \mathrm{SiO}_{2} \cdot \mathrm{Al}_{2} \mathrm{O}_{3} \cdot 8 \mathrm{H}_{2} \mathrm{O}$ in relation to the hydration of high alumina cement. Cem. Concr. Res., 8, (pp. 169-172), 1978.

(32) MIDGLEY, H. G.: The relationship between hydrate mineral content and compressive strength of set high alumina cement. Calcium Aluminates, Turin, Ed. M. Murat, 1982.

(33) RAMACHANDRAN, V. S.: "Applications of differential thermal analysis in cement chemistry". Chem. Pub. Company Limited, 1969.

(34) AMBROISE, J. MURAT, M. and PERA, J.: Hydration reaction and hardening of calcined clays and related minerals. IV. Experimental conditions for strength improvement on metakaolinite minicylinders. Cem. Concr. Res., 15, (pp. 83-88), 1985. 
(35) MURAT, M.: Hydration reaction and hardening of calcined clays and related minerals. I. Preliminary investigation on metakaolinite. Cem. Concr. Res., 13, (pp. 259-266), 1983.

(36) MACKENZIE, R. C.: "The differential thermal analysis of clays". Mineralogical Society, London, 1957.

(37) MIDGLEY, H. G.: Personal Communication.

(38) MURAT, M.: Stabilite thermique des aluminates de calcium hydrates et phases apparentees. Characterisation par les methods thermoanalytiques. Calcium Aluminates, Turin, Ed. M. Murat, 1982.

(39) GLASSER, F. P.: Personal Communication.

\section{publicaciones del ICCET/CSIC}

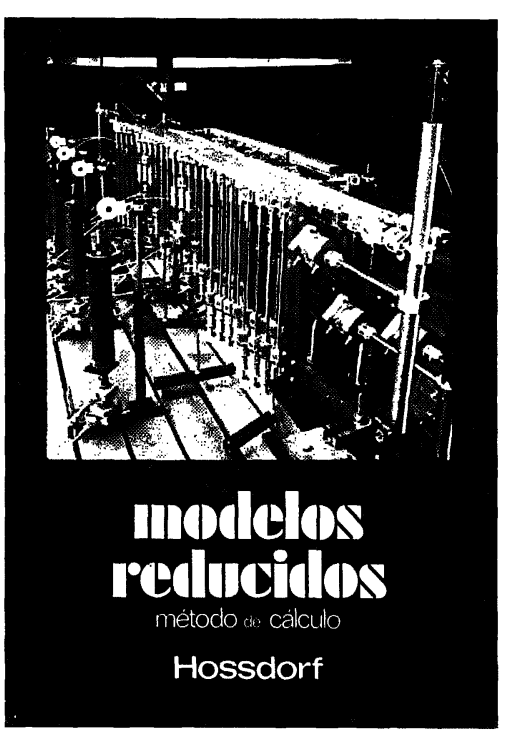

Modelos reducidos. Método de cálculo

H. Hossdorf, Ingeniero Civil

La técnica de los ensayos en modelos reducidos de estructuras sufre hoy dia una decisiva metamorfosis. estructuras sufre hoy dia una decisiva metamorfosis. Hasta hace poco era un medio más bien de artesania, que no sierizar miento resistente de las estructuras complejas $y$ al que se acudió las más de las veces, como a un ultimo remedio debido a sus indiscutibles insuficiencias. Sin embargo, en poco tiempo y gracias a su cias. Sin embargo, en poco tion y y gracias a su formado en un instrumento cientificamente valioso, que no puede quedar a un lado en la práctica diaria del Ingeniero Proyectista.

Un volumen encuadernado en cartoné plastificado con lomo de tela, de $17 \times 24 \mathrm{~cm}$, compuesto de 250 páginas, 158 figuras y fotografias.

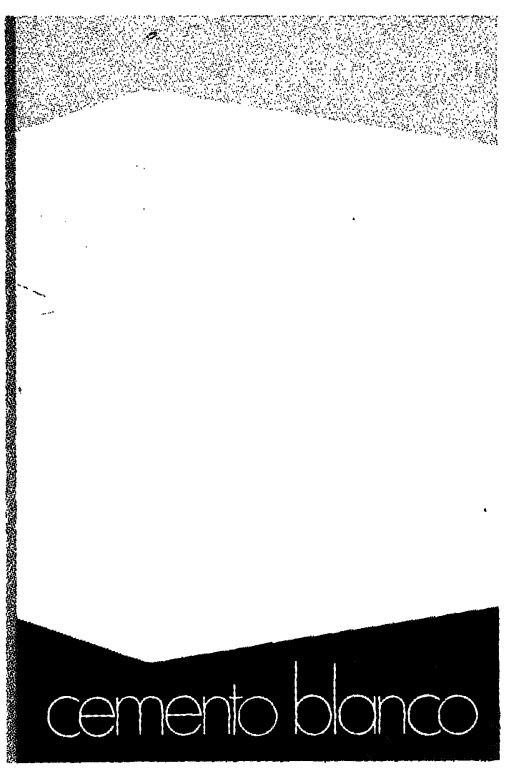

Cemento blanco

Juliàn Rezola

Ingeniero Quimico Dipl. I. O. S.

Sabido es que existe una extensa y documentada bibliografia sobre el cemento gris: en cambio, no puede decirse lo mismo acerca del cemento portland blanco, ya que los escritos existentes se refieren tan sólo a algunas peculiaridades que le distingue

El autor nos ofrece sus profundos conocimientos y su larga experiencia tanto en laboratorio como en fabricación.

La parte descriptiva del libro se complementa con gráficos, diagramas y fotografias de gran utilidad, destinados a conseguir la aplicación apropiada de este aglomerante.

Un volumen encuadernado en cartoné policerado, de $17,4 \times 24,3 \mathrm{~cm}$, compuesto de 395 páginas, numerosas figuras, tablas y ábacos.

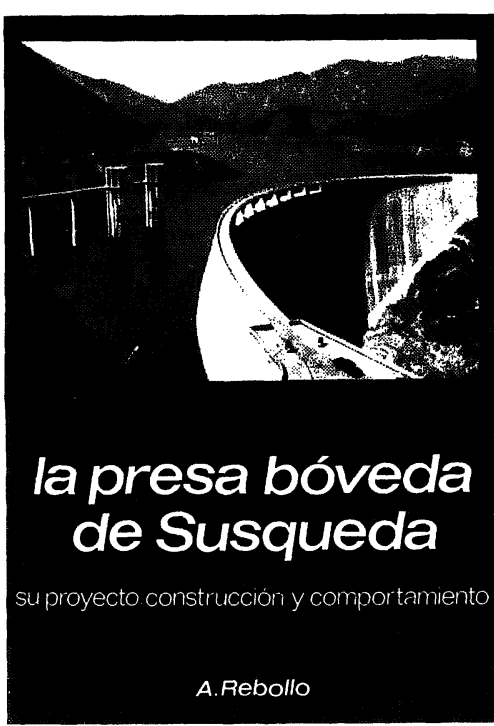

La presa bóveda de Susqueda

A. Rebollo,

Dr. Ingeniero de Caminos

El esfuerzo del constructor de presas se sitúa por su pretension de perennidad, a contracorriente de las tendencias de la civilizacion actual, caracterizada por lo fungible. Pueden evocarse las 10.000 grandes. presas en funcionamiento o en construcción que están envejeciendo $y$ reclaman los cuidados gerontológicos para mantener y perfeccionar su servicio y garantizar su inalienable pretensión de perennidad. En la medida en que todas nuevas obras, grandes o pequeñas, son portadoras de riesgos ecologicos $y$, a veces, catastroficos, que aumentan con el envejecimiento, la gerontologia de las presas es todo un emplazo. La accion adelantada de Arturo Rebollo en este tereno marca un camino a seguir para todos los que aman su propia obra con

Un volumen encuadernado en cartore nlasificado Un volumen encuadernado en cartone plastificado 408 páginas, 330 figuras y fotografias y 39 tablas. 